\title{
doi:10.1016/S0016-7037(03)00160-1
}

\section{Iron (III)-silica interactions in aqueous solution: Insights from X-ray absorption fine structure spectroscopy}

\author{
Gleb S. Pokrovski, ${ }^{1} *$ Jacques Schott, ${ }^{2}$ François Farges, ${ }^{3,4}$ and Jean-Louis Hazemann ${ }^{5}$ \\ ${ }^{1}$ Institut des Sciences de la Terre d'Orléans (ISTO), CNRS (UMR 6113), 1A rue de la Férollerie, 45071 Orléans cedex 2, France \\ ${ }^{2}$ Géochimie: Transferts et Mécanismes, CNRS (UMR 5563)-OMP-Université Paul-Sabatier, 38 rue des Trente-Six Ponts, 31400 Toulouse, France \\ ${ }^{3}$ Laboratoire des Géomatériaux, Université de Marne la Vallée and FRE CNRS 2455, 77454 Marne la Vallée cedex 2, France \\ ${ }^{4}$ Surface and Aqueous Geochemistry Group, Department of Geological and Environmental Sciences, Stanford University, \\ Stanford, CA 94305-2115, USA \\ ${ }^{5}$ LGIT and Laboratoire de Cristallographie, CNRS, B.P. 166, 38042 Grenoble, France
}

(Received August 28, 2002; accepted in revised form February 17, 2003)

\begin{abstract}
The influence of aqueous silica on the hydrolysis of iron(III) nitrate and chloride salts in dilute aqueous solutions $\left(m_{\mathrm{Fe}} \sim 0.01 \mathrm{~mol} / \mathrm{kg}\right)$ was studied at ambient temperature using X-ray absorption fine structure (XAFS) spectroscopy at the Fe K-edge. Results show that in Si-free iron nitrate and chloride solutions at acid $\mathrm{pH}(\mathrm{pH}<2.5), \mathrm{Fe}$ is hexa-coordinated with 6 oxygens of $\mathrm{H}_{2} \mathrm{O}$ - and/or $\mathrm{OH}$-groups in the first coordination sphere of the metal, at an Fe-O distance of $2.00 \pm 0.01 \AA$. With increasing $\mathrm{pH}(2.7<\mathrm{pH}<13)$, these groups are rapidly replaced by bridging hydroxyls (-OH-) or oxygens (-O-), and polymerized Fe hydroxide complexes form via $\mathrm{Fe}-(\mathrm{O} / \mathrm{OH})-\mathrm{Fe}$ bonds. In these polymers, the first atomic shell of iron represents a distorted octahedron with six $\mathrm{O} / \mathrm{OH}$ groups and $\mathrm{Fe}-\mathrm{O}$ distances ranging from 1.92 to $2.07 \AA$. The $\mathrm{Fe}$ octahedra are linked together by their edges (Fe-Fe distance $2.92-3.12 \AA$ ) and corners (Fe-Fe distance $\sim 3.47$ $\pm 0.03 \AA)$. The Fe-Fe coordination numbers $\left(N_{\text {edge }}=1-2 ; N_{\text {corner }}=0.5-0.7\right)$ are consistent with the dominant presence of iron dimers, trimers and tetramers at $\mathrm{pH} 2.5$ to 2.9, and of higher-polymerized species at $\mathrm{pH}>3$.

At $\mathrm{pH}>2.5$ in the presence of aqueous silica, important changes in $\mathrm{Fe}(\mathrm{III})$ hydrolysis are detected. In 0.05- $m$ Si solutions ( $\mathrm{pH} \sim 2.7-3.0$ ), the corner linkages between Fe octahedra in the polymeric complexes disappear, and the $\mathrm{Fe}-\mathrm{Fe}$ distances corresponding to the edge linkages slightly increase (Fe-Fe edge $\sim 3.12-3.14$ $\AA$ ). The presence of 1 to 2 silicons at $3.18 \pm 0.03 \AA$ is detected in the second atomic shell around iron. At basic $\mathrm{pH}(\sim 12.7)$, similar structural changes are observed for the iron second shell. The Fe-Si and Fe-Fe distances and coordination numbers derived in this study are consistent with (1) Fe-Si complex stoichiometries $\mathrm{Fe}_{2} \mathrm{Si}_{1-2}$ and $\mathrm{Fe}_{3} \mathrm{Si}_{2-3}$ at $\mathrm{pH}<3$; (2) structures composed of Fe-Fe dimers and trimers sharing one or two edges of $\mathrm{FeO}_{6}$-octahedra; and (3) silicon tetrahedra linked to two neighboring $\mathrm{Fe}$ octahedra via corners. At higher Si concentration $(0.16 \mathrm{~m}$, polymerized silica solution) and $\mathrm{pH} \sim 3$, the signal of the Fe second shell vanishes indicating the destruction of the Fe-Fe bonds and the formation of different Fe-Si linkages. Moreover, $\sim 20$ mol. $\%$ of $\mathrm{Fe}$ is found to be tetrahedrally coordinated with oxygens in the first coordination shell $\left(R_{\mathrm{Fe}-\mathrm{O}}=1.84\right.$ $\AA$ A). This new finding implies that Fe may partially substitute for $\mathrm{Si}$ in the tetrahedral network of the silica polymers in $\mathrm{Si}$-rich solutions.

The results of this study demonstrate that aqueous silica can significantly inhibit iron polymerization and solid-phase formation, and thus increase the stability and mobility of Fe(III) in natural waters. The silica "poisoning" of the free corner sites of iron-hydroxide colloids should reduce the adsorption and incorporation of trace elements by these colloids in Si-rich natural waters. Copyright $(C) 2003$ Elsevier Ltd
\end{abstract}

\section{INTRODUCTION}

The motivation of this study is the improved quantification of the interactions of iron with silica in aquatic surface environments. Such information is crucial to better understand the effect of aqueous silica on the geochemical cycle of iron and related trace elements. Iron (III) oxides and hydroxides play an important role in a variety of environmental and industrial processes, such as chemical weathering, soil formation, and water treatment for purification and consumer use. Colloidal and amorphous $\mathrm{Fe}$ (III) oxy-hydroxides are important adsorbents for many toxic organic and inorganic substances in natural waters, and thus they significantly influence the fate and

* Author to whom correspondence should be addressed at present address: Géochimie: Transferts et Mécanismes CNRS (UMR 5563)OMP-Université Paul Sabatier, 38 rue des 36 Ponts, 31400 Toulouse, France (gleb@lmtg.ups-tlse.fr); LL107-108-Bailey. toxicity of trace cations and anions in aquatic environments (e.g., Tessier et al., 1985; Manceau et al., 2000; Pokrovsky and Schott, 2002).

Silicic acid, $\mathrm{Si}(\mathrm{OH})_{4}$, is a major component of natural waters, attaining concentrations as high as $100 \mathrm{mg} / \mathrm{L}$. There is ample evidence of silica-iron association in both surficial and hydrothermal processes. Important amounts of silica are incorporated into natural Fe-hydroxide precipitates such as ferrihydrite (Carlson and Schwertmann, 1981; Schwertmann and Taylor, 1989; Konhauser and Ferris, 1996). A strong chemical affinity between $\mathrm{Fe}(\mathrm{III})$ and $\mathrm{Si}$ is demonstrated by the formation, under both natural and laboratory conditions, of iron silicates like nontronite, ferric chlorites/serpentines and smectites (e.g., Decarreau et al., 1987; Bailey, 1988; Toth and Fritz, 1997; Drief et al., 2001, and references therein). The presence of silica in solution significantly influences Fe(III) hydrolysis and precipitation. For example, aqueous silica inhibits goethite 
formation from solution and prevents colloidal Fe(III) hydroxides from coagulating (Schenk and Weber, 1968; Anderson and Benjamin, 1985; Vempati and Loeppert, 1989). The formation of ferryhydrite over lepidocrocite during oxidation of $\mathrm{Fe}^{2+}$ solutions is favored in the presence of silicic acid (e.g., Schwertmann and Thalmann, 1976; Mayer and Jarrel, 1996). Despite that several studies have been devoted to adsorption and incorporation of aqueous silica onto $\mathrm{Fe}$ (III) (oxy)hydroxides (McPhail et al., 1972; Sigg and Stumm, 1980; Hansen et al., 1994a, 1994b; Davis et al., 2002), little is known about the molecular structure of iron-silicate surface complexes and the position of silicon atoms in the iron (III) solids. Quantitative information about the stoichiometry and stability of Fe-Si complexes in aqueous solution is limited to $\mathrm{FeSiO}(\mathrm{OH})_{3}{ }^{2+}$ that forms at acid $\mathrm{pH}$ between $\mathrm{Fe}^{3+}$ and monomeric $\mathrm{Si}(\mathrm{OH})_{4}(\mathrm{We}-$ ber and Stumm, 1965; Olson and O'Melia, 1973; Reardon, 1979). Structural aspects of the interactions between silicic acid and ferric iron hydroxide complexes during Fe(III) hydrolysis are, however, poorly known. The aim of the present work is to use X-ray Absorption Fine Structure (XAFS) measurements at the $\mathrm{Fe} \mathrm{K}$-edge to characterize the local environment around $\mathrm{Fe}$ in dilute aqueous solutions in the presence of dissolved silica over a wide range of $\mathrm{pH}$.

In many studies dealing with iron hydrolysis in concentrated solutions $(>0.1 \mathrm{~m})$ and surface complexation of cations and anions with $\mathrm{Fe}$ (III) oxy-hydroxides and colloids (e.g., Combes et al., 1989, 1990; Waychunas et al., 1993; Bottero et al., 1994; Manceau and Charlet, 1994; Rose et al., 1997a; Manceau et al., 2000, and references therein), XAFS spectroscopy was the chosen method because it provides quantitative information at the atomic scale about the local structural environment of $\mathrm{Fe}$ and other elements in any system, including their aqueous and surface complexes (ligand's identity and number, and interatomic distances). Until now, however, the exact structural position of silicon in Fe-dominated solids or solutions could not be detected by XAFS spectroscopy, because the weak signal from the light silicon backscaterers at the Fe K-edge $(\sim 7100$ $\mathrm{eV}$ ) is usually masked by the presence of heavier atoms $(\mathrm{Fe})$ in concentrated iron solutions (e.g., Doelsh et al., 2000) or Sibearing iron hydroxides (Manceau et al., 1995). Although limited information about the structural environment around silicon (and similar light elements like Al, P; e.g., Rose et al., 1997a; Ildefonse et al., 1998; Gehlen et al., 2002) can be also obtained at the Si K-edge $(\sim 1800 \mathrm{eV})$, the low energy provides a short spectral range, and usually requires high $\mathrm{Si}$ concentrations and heroic efforts to diminish the absorption by the sample environment. In contrast, currently available third-generation synchrotron radiation sources allow XAFS analyses in the fluorescence mode at iron K-edge at Fe concentrations as low as $10^{-2}$ to $10^{-3} \mathrm{~m}$. Although such concentrations are higher than those usually encountered for $\mathrm{Fe}$ in natural waters, they are low enough to significantly slow down Fe(III) polymerization and precipitation, and to allow accurate characterization of $\mathrm{Fe}-\mathrm{Si}$ interactions (complexation) which can be easily masked by Fe-Fe condensation and solid-phase formation at higher Fe concentrations. Therefore, it is expected that the XAFS results obtained in this study should help in the refinement of aqueous and surface complexation models of $\mathrm{Fe}(\mathrm{III})_{\mathrm{aq}} / \mathrm{Fe}$ hydroxides with silica and other trace oxy-anions which could be used for better understanding of the behavior of iron in natural waters and its role in the scavenging of inorganic and organic compounds.

\section{MATERIAL AND METHODS}

\subsection{Sample Preparation}

Iron(III)-bearing aqueous solutions for XAFS (X-ray Absorption Fine Structure) experiments were prepared by dissolving weighted amounts of hydrated ferric nitrate $\left(\mathrm{Fe}\left(\mathrm{NO}_{3}\right)_{3} \cdot 9 \mathrm{H}_{2} \mathrm{O}, 99.99 \%\right.$, Aldrich Chemicals) or ferric chloride ( $\sim 0.6-m \mathrm{FeCl}_{3}$ aqueous solution, Merck Chemicals) in doubly de-ionized water. The iron content of the initial solutions was checked by flame Atomic Absorption and was found to be close to the theoretical concentration within $2 \%$ of the total value. The $\mathrm{pH}$ of the solutions was adjusted by adding 1- $m$ nitric $\left(\mathrm{HNO}_{3}\right)$ or hydrochloric $(\mathrm{HCl})$ acid, or 1- $m$ tetramethylammonium hydroxide $\left(\mathrm{N}\left(\mathrm{CH}_{3}\right)_{4} \mathrm{OH}\right)$ Titrisol solutions; it was measured before and after each experiment with a combination $\mathrm{pH}$ glass electrode (SCHOTT-H61) calibrated on the activity scale using the NIST tartrate, phthalate, phosphate and borate buffers $\left(\mathrm{pH}_{20^{\circ} \mathrm{C}}=1.69,4.00,6.87\right.$ and 9.21, respectively) and $0.1-m \mathrm{HCl}$ and $0.01-m \mathrm{NaOH}$ solutions $\left(\mathrm{pH}_{20^{\circ} \mathrm{C}}=\right.$ 1.11 and 12.12 , respectively). Silicic acid $\left(\mathrm{H}_{4} \mathrm{SiO}_{4}\right)$ was introduced into the Fe-bearing solutions as weighted amounts of a $0.67-m$ Si solution, prepared by equilibration of amorphous silica powder $\left(\mathrm{SiO}_{2} \cdot 2.2 \mathrm{H}_{2} \mathrm{O}\right)$ at ambient temperature in a $0.5-m$ tetramethylammonium hydroxide solution. Tetramethylammonium was chosen in this study as the major cation, because of its extremely low complexing affinity for metals in aqueous solution (Wesolowski et al., 1995) even in comparison to other commonly used background cations $\left(\mathrm{Na}^{+}, \mathrm{K}^{+}\right)$. The influence of $\left(\mathrm{CH}_{3}\right)_{4} \mathrm{~N}^{+}$on $\mathrm{Fe}$ hydrolysis and $\mathrm{Fe}-\mathrm{Si}$ complexing in solution can thus be neglected when analyzing XAFS spectra. To avoid possible polymerization and/or precipitation during sample preparation, solutions were vigorously stirred using a magnetic stirrer during mixing and $\mathrm{pH}$ adjustment, and then immediately filtered through a $0.2-\mu \mathrm{m}$ Millipore filter. This procedure was expected to eliminate possible heterogeneous nucleation sites and, thus, to delay significantly colloidal and solidphase formation (see below). Measurements were started within $1 \mathrm{~h}$, and completed usually within $5 \mathrm{~h}$ after solution preparation. Iron and silica concentrations in the experimental solutions used for XAFS experiments were 0.01 and $0.05 \mathrm{~m}$, respectively (with exception of a single $\mathrm{FeCl}_{3}$ solution containing $0.16 \mathrm{~m}$ silica). Such high silica concentrations were chosen to allow unambiguous detection of the light silicon backscaterers (see below). The $\mathrm{pH}$ of most solutions ranged from 1 to 3, which corresponds to $\mathrm{H} / \mathrm{Fe}$ and $\mathrm{OH} / \mathrm{Fe}$ hydrolysis total molal ratios from $\sim 10$ to $\sim 0.1$, and from $\sim 0.1$ to $\sim 4$ (depending on $\mathrm{Si}$ concentration), respectively. At $\mathrm{pH}>3$ in both Si-free and Si-bearing solutions, rapid precipitation of Fe-hydroxide was observed; however, at strongly basic $\mathrm{pH}(\mathrm{pH}=12-13, \mathrm{OH} / \mathrm{Fe}>5-10)$ this precipitate dissolved yielding a clear purple solution whose XAFS spectrum was also recorded (Tables 2-4). Monomeric silica, total $\mathrm{Si}$ and total $\mathrm{Fe}$ concentrations were determined using the molybdate blue colorimetric method (Koroleff, 1976), ICP-MS (Inductively Coupled Plasma Mass Spectrometry; see details in Pokrovski and Schott, 1998), and flame atomic absorption spectroscopy (Pokrovski et al., 2002a), respectively. Selected solutions before and after XAFS measurements were filtered through a $0.2-\mu \mathrm{m}$ filter, diluted to 5 to $20 \mathrm{ppm}$ of $\mathrm{Fe}$ and $\mathrm{Si}$, and stabilized by 2 wt. $\% \mathrm{HNO}_{3}$ for analyses of total $\mathrm{Fe}$ and $\mathrm{Si}$ performed after the XAFS session. Monomeric silica was analyzed as a function of $\mathrm{pH}(2.00,3.65$ and 10.95) and time elapsed (from few minutes to $5 \mathrm{~h}$ ) after preparation in $0.05-\mathrm{m} \mathrm{Si}$ solutions prepared exactly in the same manner as the experimental ones. Each of these solutions was diluted at constant $\mathrm{pH}$ to 7 to $10 \mathrm{ppm}$ of $\mathrm{Si}$ with aqueous $\mathrm{HNO}_{3}$ or $\mathrm{N}\left(\mathrm{CH}_{3}\right)_{4} \mathrm{OH}$ and analyzed for $\mathrm{Si}(\mathrm{OH})_{4}$ with an Autoanalyser II Technicon colorimeter (molybdate blue method) from $2 \mathrm{~min}$ to $1 \mathrm{~h}$ after dilution. This procedure allows, even at alkaline $\mathrm{pH}$ where the kinetics of depolymerization is very fast, to measure only monomeric silicic acid (and, possibly, silicic acid dimers) present in the initial concentrated solution (Koroleff, 1976; Iler, 1979; Dietzel and Usdowski, 1995). Analyses performed on solutions before and after XAFS spectra acquisition showed no changes in total $\mathrm{Si}$ and $\mathrm{Fe}$ concentrations in the limit of the analytical uncertainties ( $\pm 5 \%$ of total concentration). 
Table 1. Structural parameters of the Fe(III) atomic environment in iron-bearing solids derived in this study from fitting Fe K-edge EXAFS spectra, and comparison with X-ray diffraction (XRD) data.

\begin{tabular}{|c|c|c|c|c|c|c|c|c|}
\hline \multirow[b]{2}{*}{ Compound, chemical formula } & \multicolumn{4}{|c|}{ EXAFS $^{\mathrm{a}}$} & \multicolumn{4}{|c|}{ XRD } \\
\hline & Atom & $\begin{array}{c}R_{\text {EXAFS }} \\
(\AA)\end{array}$ & $N_{\text {EXAFS }}$ & $\begin{array}{c}\sigma^{2} \\
\left(\AA^{2}\right) \\
\end{array}$ & Atom & $\begin{array}{c}R_{\mathrm{XRD}} \\
(\AA)\end{array}$ & $N_{\mathrm{XRD}}$ & Ref. $^{\mathrm{b}}$ \\
\hline Iron (III) nitrate, $\mathrm{Fe}\left(\mathrm{NO}_{3}\right)_{3} \cdot 9 \mathrm{H}_{2} \mathrm{O}$ & $\mathrm{O}$ & 2.00 & 5.5 & 0.003 & $\begin{array}{l}\mathrm{O} 1 \\
\mathrm{O} 2\end{array}$ & $\begin{array}{l}1.974 \\
1.986\end{array}$ & $\begin{array}{l}2 \\
4\end{array}$ & HB \\
\hline Epidote, $\mathrm{Ca}_{2} \mathrm{Al}_{2.17} \mathrm{Fe}_{0.81} \mathrm{Si}_{3} \mathrm{O}_{12} \mathrm{OH}$ & $\begin{array}{l}\mathrm{O} 1 \\
\mathrm{O} 2 \\
\mathrm{O} 3 \\
\mathrm{~A} 1 \\
\mathrm{Si} 1+\mathrm{Ca} 1 \\
\mathrm{Si} 2 \\
\mathrm{Ca} 2\end{array}$ & $\begin{array}{l}1.88 \\
2.00 \\
2.24 \\
2.95 \\
3.28 \\
3.46 \\
3.74\end{array}$ & $\begin{array}{l}1.7 \\
1.8 \\
1.7 \\
2 \mathrm{f}^{\mathrm{c}} \\
4 \mathrm{f} \\
2 \mathrm{f} \\
3 \mathrm{f}\end{array}$ & $\begin{array}{l}0.002 \\
0.001 \\
0.015 \\
0.004 \\
0.007 \\
0.002 \\
0.015\end{array}$ & $\begin{array}{l}\mathrm{O} 1 \\
\mathrm{O} 2 \\
\mathrm{O} 3 \\
\mathrm{O} 4 \\
\mathrm{~A} 11 \\
\mathrm{Si} 1 \\
\mathrm{Ca} 1 \\
\mathrm{Si} 2 \\
\mathrm{Ca} 2\end{array}$ & $\begin{array}{l}1.88 \\
1.95 \\
2.00 \\
2.24 \\
2.99 \\
3.26-3.29 \\
3.29 \\
3.46 \\
3.64-3.86\end{array}$ & $\begin{array}{l}1 \\
1 \\
2 \\
2 \\
2 \\
3 \\
1 \\
2 \\
3\end{array}$ & $\mathrm{D}$ \\
\hline Goethite, $\alpha$-FeOOH & $\begin{array}{l}\mathrm{O} 1 \\
\mathrm{O} 2 \\
\mathrm{Fe} 1 \\
\mathrm{Fe} 2 \\
\mathrm{Fe} 3\end{array}$ & $\begin{array}{l}1.94 \\
2.08 \\
3.03 \\
3.28 \\
3.44\end{array}$ & $\begin{array}{l}3.1 \\
2.5 \\
2 \mathrm{f} \\
2 \mathrm{f} \\
4 \mathrm{f}\end{array}$ & $\begin{array}{l}0.005 \\
0.006 \\
0.005 \\
0.006 \\
0.008\end{array}$ & $\begin{array}{l}\mathrm{O} 1 \\
\mathrm{O} 2 \\
\mathrm{Fe} 1 \\
\mathrm{Fe} 2 \\
\mathrm{Fe} 3\end{array}$ & $\begin{array}{l}1.953 \\
2.09 \\
3.01 \\
3.28 \\
3.46\end{array}$ & $\begin{array}{l}3 \\
3 \\
2 \\
2 \\
4\end{array}$ & $\mathrm{~S}$ \\
\hline$\gamma$ - $\mathrm{LiAlO}_{2}$ with 1 wt. $\% \mathrm{Fe}^{3+}$ & $\begin{array}{l}\mathrm{O} \\
\mathrm{Al}\end{array}$ & $\begin{array}{l}1.86 \\
3.15\end{array}$ & $\begin{array}{l}3.1 \\
4.2\end{array}$ & $\begin{array}{l}0.0005 \\
0.007\end{array}$ & $\begin{array}{l}\mathrm{O} \\
\mathrm{Al}\end{array}$ & $\begin{array}{l}1.82^{\mathrm{d}} \\
3.12\end{array}$ & $\begin{array}{l}4^{\mathrm{d}} \\
4\end{array}$ & $\begin{array}{l}\text { WR } \\
M\end{array}$ \\
\hline Error of EXAFS fit & & \pm 0.01 & \pm 0.5 & $\pm 30 \%$ & & & & \\
\hline
\end{tabular}

${ }^{a} R=$ Fe-neighbor mean distance, $N=$ Fe coordination number, $\sigma^{2}=$ squared Debye-Waller factor (relative to $\sigma^{2}=0$ adopted in the calculation of reference amplitude functions by FEFF, see text).

${ }^{\mathrm{b}}$ References for XRD data: HB: Hair and Beattie (1977); D: Dollase (1971); S: Szytula et al. (1968); M: Marezio (1965), WR: Waychunas and Rossman (1983).

${ }^{\mathrm{c}} f=$ parameter was fixed to crystallographic value during fit.

d parameters derived from EXAFS fitting.

Silicic acid remained essentially monomeric ( $\sim 90 \%$ of total $\mathrm{Si})$ in the alkaline solutions during experiments. This is in agreement with equilibrium calculations using the stabilities of silicate oligomers formed in basic solutions (Baes and Mesmer, 1976). In acid solutions, silica polymerization occurred within few minutes, and only 15 to $20 \%$ of total $\mathrm{Si}$ was found to be monomeric, depending on solution $\mathrm{pH}(2-3.65)$ and time (few minutes to $5 \mathrm{~h}$ ). Nevertheless, the structural environment of Fe derived from the XAFS spectra was found to be insensitive to the degree of silica polymerization (see below). In a solution with the highest $\mathrm{Si}$ concentration $(0.16 \mathrm{~m})$ at $\mathrm{pH} \mathrm{3}$, a silica gel was observed after measurements. No significant $\mathrm{pH}$ changes $( \pm 0.1-0.2 \mathrm{pH}$ unit) were recorded after experiments for all solutions. Although the majority of solutions at $\mathrm{pH}>2$ were significantly supersaturated with respect to $\mathrm{Fe}$ oxy-hydroxides $\left(\alpha-\mathrm{FeOOH}\right.$, amorphous $\left.\mathrm{Fe}[\mathrm{OH}]_{3}\right)$, the constancy of $\mathrm{Fe}$ and $\mathrm{Si}$ concentrations and $\mathrm{pH}$, measured before and after experiments on solutions filtered through $0.2-\mu \mathrm{m}$ membrane filters, indicates that no precipitation of $\mathrm{Fe}$ (or $\mathrm{Fe}-\mathrm{Si}$ ) solid phases occurred during measurements. However, the presence of nano-particles of such phases or colloids, which could have passed through the $0.2-\mu \mathrm{m}$ filter, cannot be completely excluded on the bases of chemical analyses only. Nevertheless, XAFS analysis indicates that such particles were likely to be insignificant in our solutions. First, successive EXAFS scans, recorded in this study during at least 3 to $5 \mathrm{~h}$ for all solutions, were very similar for each given sample and were without suspicious noise and flaws, thus demonstrating that the local atomic environment of Fe remains the same in the experimental solutions. Second, as it will be shown below (section 3), the number of Fe-Fe neighbors derived from the EXAFS spectra of acid solutions corresponded to the dominant presence of small $\mathrm{Fe}$ polymeric species, and was much lower than what would be expected for Fe-bearing solid/colloidal particles. This indicates that no significant solid-phase formation occurred over at least the time of measurements $(<5 \mathrm{~h})$.

\subsection{XAFS Spectra Acquisition and Data Reduction}

XAFS spectra (including the X-ray absorption near edge structure region or XANES, and the extended X-ray absorption fine structure region or EXAFS) were collected at ambient temperature $\left(20 \pm 1^{\circ} \mathrm{C}\right)$ in the fluorescence mode at the Fe K-edge $(\sim 7130 \mathrm{eV})$ over the energy range 7000 to $8000 \mathrm{eV}$ on the collaborative research group IF BM32 beamline at the European Synchrotron Radiation Facility (ESRF, Grenoble, France). The storage ring was operated at $6 \mathrm{GeV}$ with a 200-150 mA current. The beam energy was selected using a $\mathrm{Si}(111)$ double crystal monochromator with dynamical sagittal focussing. The fluorescence spectra were collected using a Canberra 30-element solidstate detector. The solutions were placed in a special Teflon cell with Kapton-film windows. The cell handling and spectra acquisition procedure were similar to those described in Pokrovski et al. (2000, 2002b). To obtain the necessary signal-to-noise ratio for quantifying next-nearest neighbors $(\mathrm{Fe}, \mathrm{Si})$ around the absorbing $\mathrm{Fe}$ atoms, three scans (of $\sim 50 \mathrm{~min} / \mathrm{scan}$ data collection time) for each solution were collected to high energy values (up to $k=14-15 \AA^{-1}$, where $k$ is the photo-electron momentum). After acquisition, all scans for each sample were carefully inspected for each individual solid state detector and, if found reasonably free of beam intensity fluctuations and other flaws, were added together. Goethite, $\alpha-\mathrm{FeOOH}$, ferric iron nitrate, $\mathrm{Fe}\left(\mathrm{NO}_{3}\right)_{3} \cdot 9 \mathrm{H}_{2} \mathrm{O}$, epidote, $\mathrm{Ca}_{2}\left(\mathrm{Al}, \mathrm{Fe}^{3+}\right)_{3}\left(\mathrm{Si}_{2} \mathrm{O}_{7}\right)\left(\mathrm{SiO}_{4}\right)(\mathrm{O}, \mathrm{OH})_{2}$, and $\mathrm{LiAlO}_{2}$ doped with 1 wt. $\%$ of $\mathrm{Fe}^{3+}$, which can serve as model compounds for Fe local environment (see Wilke et al., 2001), were recorded in the transmission mode to exclude self-absorption effects.

Data analysis was performed with the XAFS 2.6 package (Winterer, 1997) using the "standard" procedure (Teo, 1986). Details about spectra reduction can be found in Pokrovski et al. (2002b). Briefly, the before-edge spectral region $(7000-7100 \mathrm{eV})$ was fitted using a straight line and subtracting this from the whole spectrum. Then, the spectra were normalized for atomic absorption, based on the average absorp- 


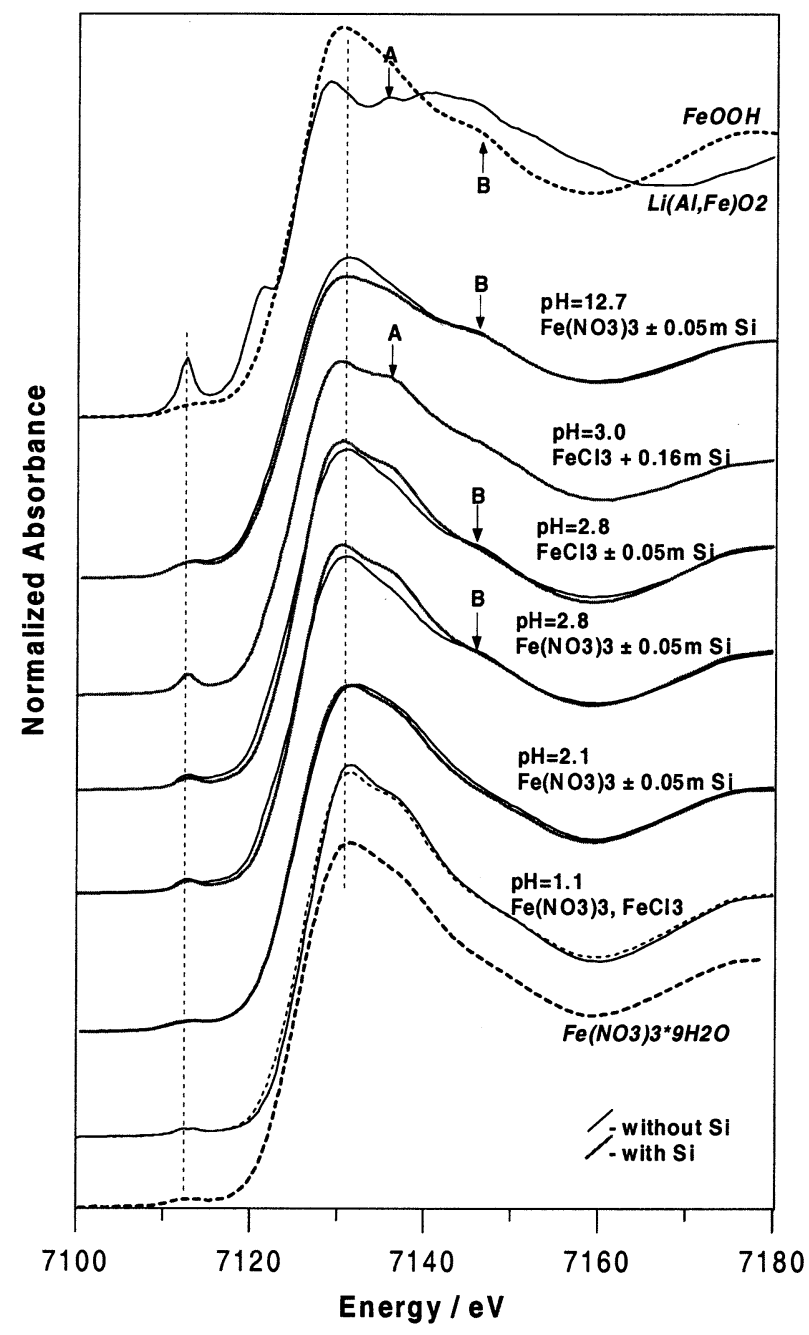

Fig. 1. XANES spectra at Fe K-edge of selected Fe-bearing solutions and solids. The vertical dashed lines indicate the pre-edge feature and main edge of iron. Arrows labeled A and B denote different main-edge features discussed in the text.

tion coefficient of the spectral region 7200 to $7400 \mathrm{eV}$. Pre-edge features were processed by subtracting a 2-degree polynomial fit to the absorption background, $2 \mathrm{eV}$ from both sides of the prepeak, to determine the pre-edge intensity (normalized to the main-edge), peak area and half-height width. Background above the edge was determined by fitting cubic spline functions. Energies were recalculated into $k$-space $\left(\AA^{-1}\right)$ with $E_{0}$ (i.e., the energy where $k$ is zero) arbitrarily chosen at zero of the main edge first derivative. Normalized background-subtracted EXAFS spectra were weighted by $k^{3}$, filtered over the $k$ range from $\sim 3$ to $13-14 \AA^{-1}$, and Fourier-transformed (Kaiser-Bessel window with $\tau$ values of 2.5) to produce radial distribution functions (RDF) that isolate different atomic shells. To extract structural information, one or several RDF contributions were back-transformed into momentum space and modeled by least-square fitting. This gives the identity of the backscattering atoms (e.g., $\mathrm{O}, \mathrm{Si}$, or $\mathrm{Fe}$ ), $\mathrm{Fe}$-neighbor distance $(R)$ and coordination number $(N)$, and the Debye-Waller factor $\left(\sigma^{2}\right)$ for a given scattering path. In addition to these structural parameters, a single nonstructural parameter, $\Delta E_{0}$, was varied in initial fits to account for its estimate made by FEFF (see below). It was found that the optimal value of $\Delta E_{0}$ varied within $< \pm 2 \mathrm{eV}$ for most reference solids and aqueous samples. Raw EXAFS spectra were also fitted with multiple shells; they produced values of structural parameters similar to those extracted from fits of filtered signals for an individual shell. For

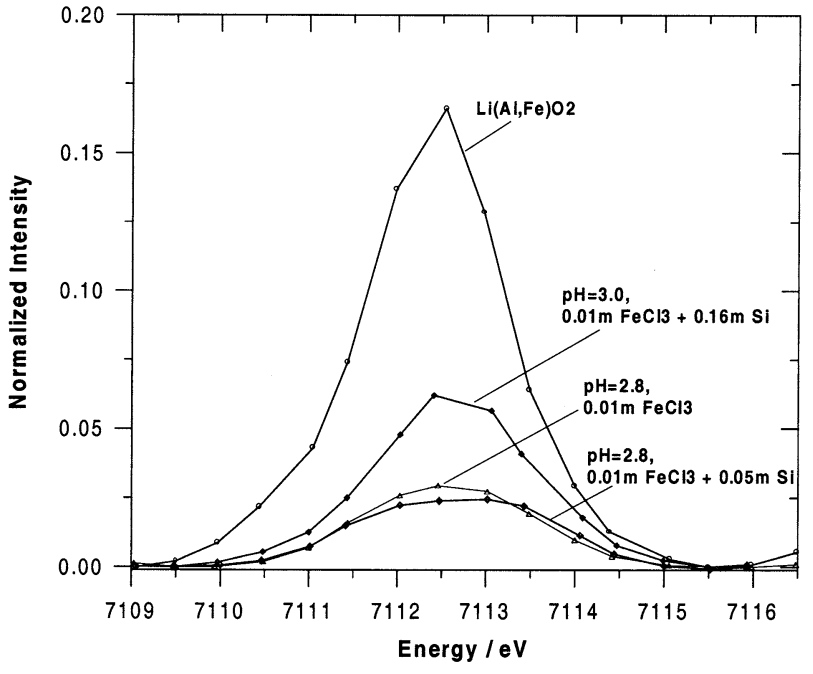

Fig. 2. Pre-edge features of selected 0.01- $m \mathrm{FeCl}_{3}$ solutions and ferric lithium aluminate. Note a significant enhancement of the preedge intensity for the $0.16-m \mathrm{Si}$ solution, suggesting the presence of tetracoordinated $\mathrm{Fe}$ like in $\mathrm{Li}(\mathrm{Al}, \mathrm{Fe}) \mathrm{O}_{2}$.

most spectra which showed weak second shell contributions around $\mathrm{Fe}$, fits of the total EXAFS spectrum were, however, less robust and exhibited larger uncertainties than those for the individual shell fits. Consequently, the results of the latter models were considered to be more reliable and they are reported in this study. Theoretical backscattering amplitude and phase-shift functions for $\mathrm{Fe}-\mathrm{O}$ and $\mathrm{Fe}-\mathrm{Si}$, Fe-Fe, and $\mathrm{Fe}-\mathrm{Cl}$ pairs were computed using the FEFF 8 ab initio code (Ankudinov et al., 1998), assuming the local structure around $\mathrm{Fe}$ in andradite garnet, $\mathrm{Ca}_{3} \mathrm{Fe}_{2} \mathrm{Si}_{3} \mathrm{O}_{12}$ (Hazen and Finger, 1989), $\alpha$-FeOOH (Szytula et al., 1968), and $\mathrm{FeOCl}$ (Lind, 1970), respectively. The validity of the generated amplitude and phase functions was checked by fitting EXAFS spectra of Fe(III)-bearing solids. Interatomic distances and coordination numbers derived from fitting of model compounds are in close agreement with those obtained by X-ray Diffraction (XRD) in the limit of $\pm 0.02 \AA$ and \pm 0.5 atoms for first and next-nearest atomic shells (Table 1). The influence of anharmonic disorder in determining structural parameters was checked using the cumulant expansion method (Crozier et al., 1988; Farges, 1996; Farges et al., 1996; Soldo et al., 1998). The typical values of third- and fourth-order cumulants $\left(\mathrm{C}_{3}\right.$ and $\left.\mathrm{C}_{4}\right)$ found when fitting the filtered signal for the Fe first coordination shell were of the order of $10^{-4}$ and, consequently, too small to affect significantly $R$ and $N$ values derived from least-square fits without cumulants. As a result, to reduce the number of variables and thus the uncertainties on the derived parameters, we choose the harmonic approximation when extracting $R, N$ and $\sigma$ values for all $\mathrm{Fe}$ atomic shells. The influence of possible multiple scattering (MS) events within the Fe first and second coordination shells on the EXAFS spectra was also tested using the FEFF code, assuming local $T_{d}$ and $\mathrm{O}_{h}$ geometries around $\mathrm{Fe}(\mathrm{III})$, as found in the model compounds investigated. However, we cannot exclude the possibility of unusual local geometries that can favor MS events. Nevertheless, with the exception of the most acid solutions ( $\mathrm{pH} \sim 1$ ), MS contributions were found to be negligible when fitting the next-nearest atomic shells.

\section{RESULTS}

\subsection{XANES Analysis}

\subsubsection{Pre-Edge region}

Normalized XANES spectra for selected Fe-bearing solutions and solids are presented in Figure 1. All spectra exhibit pre-edge features at 7112.5 $\pm 0.2 \mathrm{eV}$ (Table 2, Figs. 1 and 2), which are caused by electronic transitions from the $1 \mathrm{~s}$ to $3 \mathrm{~d}$ 
Table 2. Pre-edge and main-edge parameters from iron K-edge XANES spectra of Fe(III)-bearing solids and solutions measured in this study.

\begin{tabular}{|c|c|c|c|c|c|}
\hline \multirow[b]{2}{*}{ Sample } & \multicolumn{4}{|c|}{ Pre-edge } & \multirow{2}{*}{ 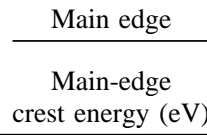 } \\
\hline & $\begin{array}{c}\text { Centroid } \\
\text { position }(\mathrm{eV})\end{array}$ & $\begin{array}{c}\text { Normalized } \\
\text { height }\end{array}$ & Peak area & $\begin{array}{l}\text { Half-width } \\
(\mathrm{eV})\end{array}$ & \\
\hline \multicolumn{6}{|l|}{ Solids } \\
\hline $\mathrm{Fe}(\mathrm{III})$ nitrate, $\mathrm{Fe}\left(\mathrm{NO}_{3}\right)_{3} \cdot 9 \mathrm{H}_{2} \mathrm{O}$ & 7112.3 & 0.016 & 0.064 & 3.7 & 7131.5 \\
\hline Goethite, $\alpha$-FeOOH & 7112.7 & 0.020 & 0.068 & 3.4 & 7130.3 \\
\hline Epidote & 7112.5 & 0.034 & 0.097 & 2.7 & 7127.6 \\
\hline $\mathrm{LiAlO}_{2}$ doped with 1 wt. $\% \mathrm{Fe}^{3+}$ & 7112.5 & 0.174 & 0.381 & 2.2 & 7129.0 \\
\hline \multicolumn{6}{|l|}{ Si-free solutions $(0.01-m \mathrm{Fe})^{\mathrm{a}}$} \\
\hline $\mathrm{Fe}\left(\mathrm{NO}_{3}\right)_{3}+0.1=m \mathrm{HNO}_{3}, \mathrm{pH} 1.15, \mathrm{H} / \mathrm{Fe}=10$ & 7112.8 & 0.020 & 0.063 & 3.2 & 7131.6 \\
\hline $\mathrm{FeCl}_{3}+0.1-m \mathrm{HCl}, \mathrm{pH} 1.10, \mathrm{H} / \mathrm{Fe}=10$ & 7112.8 & 0.020 & 0.063 & 3.2 & 7131.5 \\
\hline $\mathrm{Fe}\left(\mathrm{NO}_{3}\right)_{3}, \mathrm{pH} 2.10, \mathrm{H} / \mathrm{Fe}=1$ & 7112.6 & 0.020 & 0.070 & 3.5 & 7132.0 \\
\hline $\mathrm{Fe}\left(\mathrm{NO}_{3}\right)_{3}, \mathrm{pH} 2.36, \mathrm{OH} / \mathrm{Fe}=0$ & 7112.5 & 0.022 & 0.068 & 3.2 & 7131.3 \\
\hline $\mathrm{Fe}\left(\mathrm{NO}_{3}\right)_{3}, \mathrm{pH} 2.80, \mathrm{OH} / \mathrm{Fe}=2.8$ & 7112.5 & 0.032 & 0.078 & 2.5 & 7130.9 \\
\hline $\mathrm{FeCl}_{3}, \mathrm{pH} 2.80, \mathrm{OH} / \mathrm{Fe}=2.8$ & 7112.5 & 0.032 & 0.074 & 2.5 & 7130.9 \\
\hline $\mathrm{Fe}\left(\mathrm{NO}_{3}\right)_{3}, \mathrm{pH} 12.9, \mathrm{OH} / \mathrm{Fe}=15$ & 7112.5 & 0.026 & 0.101 & 3.9 & 7131.2 \\
\hline \multicolumn{6}{|l|}{ Si-bearing solutions $(0.01-m \mathrm{Fe})^{\mathrm{a}}$} \\
\hline $\mathrm{Fe}\left(\mathrm{NO}_{3}\right)_{3}+0.05-m \mathrm{Si}, \mathrm{pH} 2.10, \mathrm{OH} / \mathrm{Fe}=0$ & 7112.6 & 0.023 & 0.095 & 4.0 & 7131.5 \\
\hline $\mathrm{Fe}\left(\mathrm{NO}_{3}\right)_{3}+0.05-m \mathrm{Si}, \mathrm{pH} 2.80, \mathrm{OH} / \mathrm{Fe}=2.0$ & 7112.6 & 0.027 & 0.078 & 2.7 & 7130.5 \\
\hline $\mathrm{FeCl}_{3}+0.05-m \mathrm{Si}, \mathrm{pH} 2.80, \mathrm{OH} / \mathrm{Fe}=2.0$ & 7112.6 & 0.024 & 0.078 & 2.7 & 7130.5 \\
\hline $\mathrm{FeCl}_{3}+0.16-m \mathrm{Si}, \mathrm{pH} 2.95, \mathrm{OH} / \mathrm{Fe}=4.0$ & 7112.6 & 0.068 & 0.155 & 2.3 & 7130.3 \\
\hline $\mathrm{Fe}\left(\mathrm{NO}_{3}\right)_{3}+0.05-m \mathrm{Si}, \mathrm{pH} 12.5, \mathrm{OH} / \mathrm{Fe}=10$ & 7112.5 & 0.029 & 0.117 & 4.0 & 7131.2 \\
\hline Error of deconvolution & $\pm 0.2 \mathrm{eV}$ & $\pm 10 \%$ & $\pm 15 \%$ & $\pm 0.3 \mathrm{eV}$ & $\pm 0.5 \mathrm{eV}$ \\
\hline
\end{tabular}

${ }^{a} \mathrm{H} / \mathrm{Fe}$ and $\mathrm{OH} / \mathrm{Fe}$ stand for the molal ratio of iron salt concentration to the total added acid $\left(\mathrm{HNO}_{3}\right.$ or $\left.\mathrm{HCl}\right)$ and base $\left(\mathrm{N}\left(\mathrm{CH}_{3}\right)_{4} \mathrm{OH}\right)$ concentration, respectively, during solution preparation (see text for details).

states in the iron atom (Apted et al., 1985; Combes et al., 1989, 1990; Wilke et al., 2001). The intensity, shape and position of the pre-edge features reflect the redox state and symmetry of $\mathrm{Fe}$ sites (Wilke et al., 2001). The normalized height, peak area, and half-width of these features for experimental solutions and reference solids are summarized in Table 2. Because of the relatively low spectral resolution provided by the $\mathrm{Si}(111)$ monochromator, these pre-edge features could not be modeled precisely into different components and, therefore, were treated as a single peak.

The pre-edge parameters of both Fe nitrate and chloride solutions at acid $\mathrm{pH}(\mathrm{pH}<2.2)$ are similar to that of $\mathrm{Fe}\left(\mathrm{NO}_{3}\right)_{3} \cdot 9 \mathrm{H}_{2} \mathrm{O}$ (Table 2), in which $\mathrm{Fe}^{3+}$ is octahedrally coordinated by six $\mathrm{H}_{2} \mathrm{O}$ (Hair and Beattie, 1977). This confirms that a similar geometry around the $\mathrm{Fe}^{3+}$ cation exists in acid aqueous solution (Apted et al., 1985). With increasing $\mathrm{pH}$, the intensity of the pre-edge feature grows slightly, most likely reflecting an increased distortion of centrosymmetry within the $\mathrm{FeO}_{6}$ octahedron (although the appearance of minor amounts of four- and/or five-coordinated Fe(III) species cannot be excluded) (Combes et al., 1989; Wilke et al., 2001).

No significant differences in the pre-edge features were observed in the presence of $0.05-m \mathrm{Si}$ at $\mathrm{pH}$ from 2.1 to $\sim 13$. By contrast, at higher silica concentration $(0.16 \mathrm{~m})$ at $\mathrm{pH}=3$, the pre-edge peak is enhanced by a factor of $\sim 2$ to 3 (Fig. 2). This enhancement indicates the presence of a tetrahedral environment for $\mathrm{Fe}$ in this solution, like in solid $\mathrm{LiAlO}_{2}$ doped with $\mathrm{Fe}(\mathrm{III})$, in which $\mathrm{Fe}$ is tetracoordinated by oxygens (Waychunas and Rossman, 1983). Assuming that the pre-edge peak height and area are proportional to the percentage of tetrahedral Fe (Combes et al., 1989; Peterson et al., 1997; Wilke et al., 2001), and using the values of corresponding parameters for
$\mathrm{Li}(\mathrm{Al}, \mathrm{Fe}) \mathrm{O}_{2}$, the proportion of ${ }^{[4]} \mathrm{Fe}$ in the $0.16-m \mathrm{Si}$ solution can be estimated as $\sim 22 \pm 5 \mathrm{~mol} \%$. This value is confirmed by the EXAFS analysis (see below).

\subsubsection{Main-Edge region}

Spectra of $0.01-m \mathrm{Fe}$ nitrate and chloride silica-free and silica-bearing acid solutions $(\mathrm{pH}<2.5)$ are similar in shape and white-line positions $(\sim 7131.5 \mathrm{eV})$ to that of hydrated iron nitrate $\mathrm{Fe}\left(\mathrm{NO}_{3}\right)_{3} \cdot 9 \mathrm{H}_{2} \mathrm{O}$ suggesting the same Fe octahedral coordination. In Si-free solutions of higher $\mathrm{pH}(\mathrm{pH}>2.5)$, the edge-crests are slightly shifted to lower energies $(\sim 7131.0 \mathrm{eV})$; the spectra's shape is very similar to that of goethite $(\alpha$ $\mathrm{FeOOH}$ ) having a feature at $\sim 7148 \mathrm{eV}$ (identified by arrow B in Fig. 1). Because the goethite structure is characterized by distorted $\mathrm{FeO}_{3}(\mathrm{OH})_{3}$ octahedra linked together by their edges and corners (Manceau and Combes, 1988), similar structures could be expected in the iron oxy-hydroxide oligomer complexes formed at $\mathrm{pH}>2.5$ in solution. In the presence of $0.05-m \mathrm{Si}$ at $\mathrm{pH}$ of $\sim 2.8$, the goethite features are partially suppressed, and the spectra shape more resembles those for acid solutions. These qualitative changes in the presence of silica at $\mathrm{pH}>2.5$ might indicate a more symmetrical Fe atomic environment in $\mathrm{Fe}-\mathrm{Si}$ complexes like that at more acid $\mathrm{pH}$. At higher silica concentration (0.16- $m$ Si polymerized solution, $\mathrm{pH}$ $=3$ ), the main-edge shape and position are significantly different from those for the $0.05-m$ Si solutions. The white-line position $(7130 \mathrm{eV}$ ) and the after edge-crest feature (at $\sim 7138$ $\mathrm{eV}$, marked by arrow $\mathrm{A}$ in Fig. 1) are very close to those observed in the spectrum of $\mathrm{Li}(\mathrm{Al}, \mathrm{Fe}) \mathrm{O}_{2}$ (Fig. 1, Table 2). This similarity, together with the enhanced pre-edge feature (see 

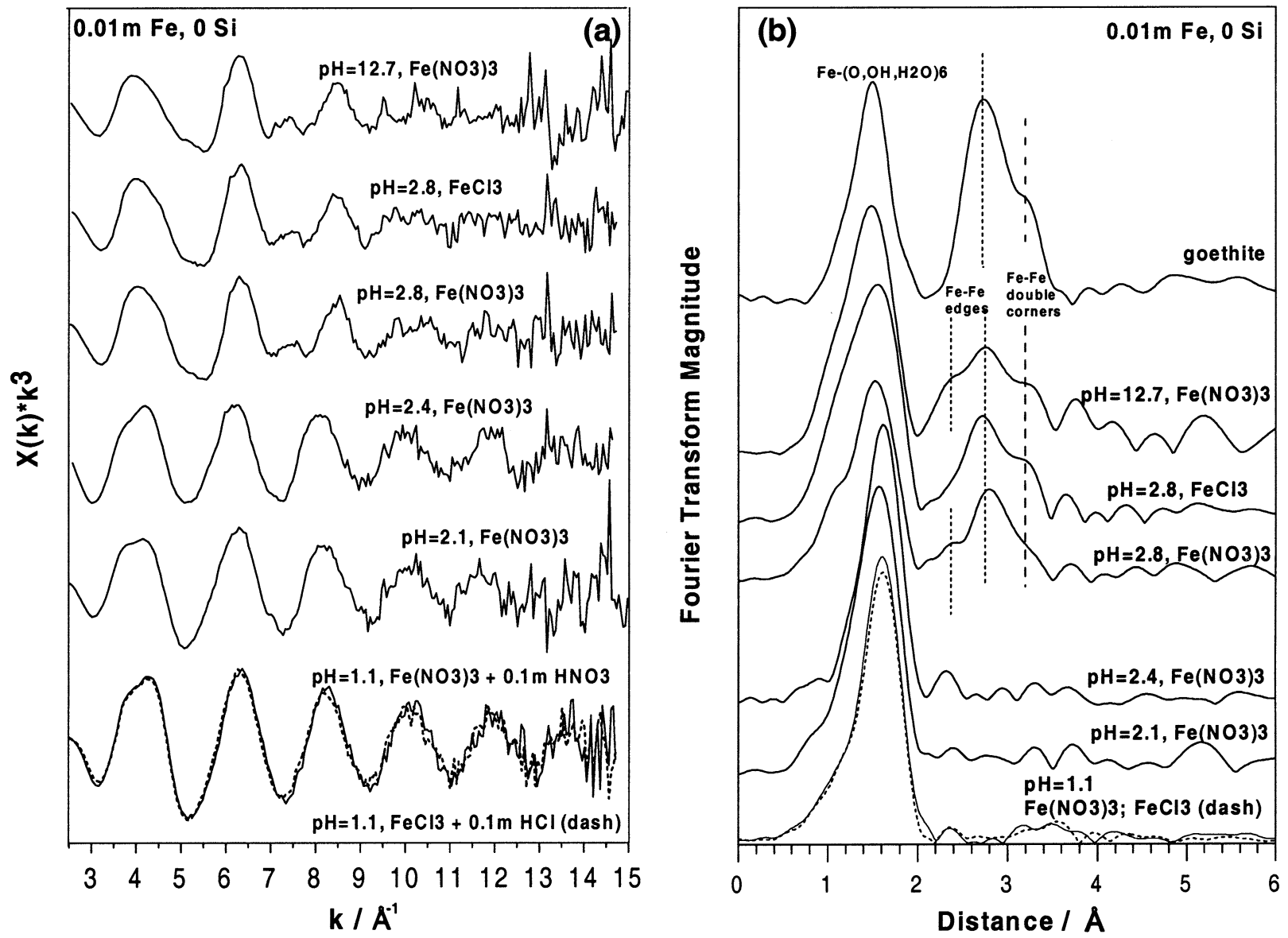

Fig. 3. $k^{3}$-weighted EXAFS spectra at Fe-K edge of selected Si-free Fe nitrate and chloride solutions as a function of $\mathrm{pH}$ (a); and their corresponding Fourier Transforms (not corrected for phase shift) (b). The vertical lines on (b) indicate $\mathrm{Fe}-\mathrm{Fe}$ edge and double-corner linkages in the polymerized Fe oxy-hydroxide complexes.

section 3.1.1), suggests the presence in this solution of iron in tetrahedral coordination.

\subsection{EXAFS Analysis of Silica-Free Solutions}

\subsubsection{First atomic shell}

Normalized $k^{3}$-weighted EXAFS spectra and their Fourier Transforms (FT) of the studied Si-free solutions are presented in Figures $3 \mathrm{a}$ and $3 \mathrm{~b}$. In strongly acid chloride and nitrate solutions $(\mathrm{pH}<2.4)$, both EXAFS and FT spectra exhibit a single contribution from a first shell of oxygens around $\mathrm{Fe}$. Modeling this signal yields $6.0 \pm 0.5$ oxygens with a mean Fe-O distance of $2.00 \pm 0.01 \AA$. This is in agreement with the EXAFS measurements of Combes et al. (1989) on highly concentrated $\mathrm{Fe}(\mathrm{III})$ hydrolyzed solutions $\left(m_{\mathrm{Fe}}>0.1 \mathrm{~m}\right)$, and consistent with the predominance of $\mathrm{Fe}\left(\mathrm{H}_{2} \mathrm{O}\right)_{6}{ }^{3+}$ and $\mathrm{Fe}\left(\mathrm{H}_{2} \mathrm{O}\right)_{5} \mathrm{OH}^{2+}$ (Baes and Mesmer, 1976). Including chlorine in the fit of the first shell contribution of the 0.01- $m \mathrm{FeCl}_{3}+$ $0.1-m \mathrm{HCl}$ solution slightly improves the fit quality, suggesting the possible presence of $\sim 0.3 \pm 0.2 \mathrm{Cl}$ atoms (Table 3 ). $\mathrm{No} \mathrm{Cl}$ atoms were detected in the first $\mathrm{Fe}$ shell of $\mathrm{FeCl}_{3} \pm \mathrm{HCl}(0.01$ $\left.<m_{\mathrm{Cl}}<0.1\right)$ solutions at higher $\mathrm{pH}$.

At $\mathrm{pH}$ from 2.4 to 2.8 in both nitrate and chloride solutions, the number of neighbors remains the same within errors as in the strongly acid solutions $\left(N_{\mathrm{Fe}-\mathrm{O}}=5.5 \pm 0.5\right)$, but the average Fe-O distance decreases by $0.03 \AA\left(R_{\mathrm{FeO}}=1.97 \AA\right)$. The first coordination sphere of $\mathrm{Fe}$ deviates a little from a regular octahedron, as indicated by an increase of the DW factor (from 0.005 to $\sim 0.01$, see Table 3 ).

At basic $\mathrm{pH}$, fits of the first $\mathrm{Fe}$ shell are consistent with two different Fe-O distances (1.92 and $2.05 \AA$ ), resembling closely the iron local environment in goethite (see Table 1). This is demonstrated in Figure 4. The EXAFS spectra of the first shell of both goethite and Fe basic solution are similar, but exhibit a distinct phase shift (indicated by the dashed line) in comparison to acid solutions.

\subsubsection{Second and third atomic shells}

At $\mathrm{pH}<2$, the minor feature observed at $\sim 3.5 \AA$ on the FT spectra (Fig. 3b, not corrected for phase shift) might correspond to both multiple scattering paths within the symmetrical $\mathrm{FeO}_{6}$ octahedron and the second solvation shell around $\mathrm{Fe}^{3+}$, by analogy with EXAFS and WAXS (wide-angle X-ray scattering) results on other trivalent cations like $\mathrm{Cr}^{3+}, \mathrm{In}^{3+}$, or $\mathrm{Ga}^{3+}$ (Lindqvist-Reis et al., 1998). At pH from 2 to 2.4, this contribution is hardly discernable, probably due to the distortion of the octahedral symmetry of the first Fe shell. The small lobes 
Table 3. Structural parameters of the first atomic shell of iron obtained from fitting Fe K-edge EXAFS spectra of 0.01 molal Fe(III)-nitrate and -chloride solutions with and without aqueous silica. ${ }^{a}$

\begin{tabular}{|c|c|c|c|c|c|c|}
\hline Solution & $\mathrm{pH}_{20^{\circ} \mathrm{C}}$ & Atomic pair & $\mathrm{R}(\AA)$ & $\mathrm{N}$ (atom) & $\sigma^{2}\left(\AA^{2}\right)$ & $\mathrm{chi}^{2}$ \\
\hline \multicolumn{7}{|l|}{ Si-free solutions } \\
\hline $\mathrm{Fe}\left(\mathrm{NO}_{3}\right)_{3}, \sim 0.1-m \mathrm{HNO}_{3}$ & 1.03 & $\mathrm{Fe}-\mathrm{O}$ & $1.996(0.002)$ & $5.9(0.3)$ & $0.003(0.0005)$ & 1.36 \\
\hline $\mathrm{Fe}\left(\mathrm{NO}_{3}\right)_{3}, \sim 0.1-m \mathrm{HNO}_{3}$ & 1.15 & $\mathrm{Fe}-\mathrm{O}$ & $1.994(0.002)$ & $6.1(0.2)$ & $0.004(0.0005)$ & 0.60 \\
\hline \multirow[t]{2}{*}{$\mathrm{FeCl}_{3}, \sim 0.1-m \mathrm{HCl}$} & 1.10 & $\mathrm{Fe}-\mathrm{O}$ & $2.002(0.003)$ & $6.0(0.2)$ & $0.004(0.0005)$ & 0.30 \\
\hline & & $\mathrm{Fe}-\mathrm{Cl}$ & $2.30(0.03)$ & $0.3(0.2)$ & $0.002(0.001)$ & \\
\hline $\mathrm{Fe}\left(\mathrm{NO}_{3}\right)_{3}$ & 2.10 & $\mathrm{Fe}-\mathrm{O}$ & $2.00(0.01)$ & $5.5(0.3)$ & $0.005(0.001)$ & 1.20 \\
\hline $\mathrm{Fe}\left(\mathrm{NO}_{3}\right)_{3}$ & 2.36 & $\mathrm{Fe}-\mathrm{O}$ & $2.02(0.01)$ & $5.0(0.5)$ & $0.005(0.001)$ & 0.23 \\
\hline $\mathrm{Fe}\left(\mathrm{NO}_{3}\right)_{3}$ & 2.80 & $\mathrm{Fe}-\mathrm{O}$ & $1.98(0.01)$ & $5.9(0.3)$ & $0.009(0.002)$ & 0.55 \\
\hline $\mathrm{FeCl}_{3}$ & 2.80 & $\mathrm{Fe}-\mathrm{O}$ & $1.97(0.02)$ & $5.5(0.4)$ & $0.010(0.003)$ & 0.60 \\
\hline \multirow[t]{2}{*}{$\mathrm{Fe}\left(\mathrm{NO}_{3}\right)_{3}$} & 12.9 & $\mathrm{Fe}-\mathrm{O} 1$ & $1.92(0.03)$ & $2.5(0.5)$ & $0.006(0.002)$ & 0.70 \\
\hline & & $\mathrm{Fe}-\mathrm{O} 2$ & $2.05(0.03)$ & $2.8(0.5)$ & $0.006(0.002)$ & \\
\hline \multicolumn{7}{|l|}{ Si-bearing solutions } \\
\hline $\mathrm{Fe}\left(\mathrm{NO}_{3}\right)_{3}, 0.05 \cdot m \mathrm{Si}$ & 2.10 & $\mathrm{Fe}-\mathrm{O}$ & $2.00(0.01)$ & $5.6(0.4)$ & $0.005(0.001)$ & 0.43 \\
\hline $\mathrm{Fe}\left(\mathrm{NO}_{3}\right)_{3}, 0.05 \cdot m \mathrm{Si}$ & 2.80 & $\mathrm{Fe}-\mathrm{O}$ & $1.995(0.005)$ & $5.9(0.3)$ & $0.009(0.002)$ & 0.57 \\
\hline $\mathrm{FeCl}_{3} 0.05-m \mathrm{Si}$ & 2.80 & $\mathrm{Fe}-\mathrm{O}$ & $1.99(0.01)$ & $6.2(0.4)$ & $0.010(0.002)$ & 0.46 \\
\hline \multirow{2}{*}{$\mathrm{FeCl}_{3}, 0.16-m \mathrm{Si}$ (colloidal) } & 2.95 & $\mathrm{Fe}-\mathrm{O} 1$ & $1.84(0.02)$ & $1.1(0.2)$ & $0.0005(0.0002)$ & 0.60 \\
\hline & & $\mathrm{Fe}-\mathrm{O} 2$ & $1.99(0.02)$ & $4.5(0.5)$ & $0.012(0.002)$ & \\
\hline \multirow[t]{2}{*}{$\mathrm{Fe}\left(\mathrm{NO}_{3}\right)_{3}, 0.05 \cdot m \mathrm{Si}$} & 12.5 & $\mathrm{Fe}-\mathrm{O} 1$ & $1.93(0.03)$ & $3.7(0.3)$ & $0.005(0.002)$ & 0.76 \\
\hline & & $\mathrm{Fe}-\mathrm{O} 2$ & $2.07(0.02)$ & $1.7(0.3)$ & $0.006(0.002)$ & \\
\hline
\end{tabular}

${ }^{a} R=$ Fe-neighbor mean distance, $N=$ Fe coordination number, $\sigma^{2}=$ squared Debye-Waller factor, chi $^{2}=N /(F \times M) \times \Sigma\left(Y_{\exp }^{2}-Y_{\text {fit }}{ }^{2}\right)$, where $N=$ number of independent data, $F=$ degrees of freedom, $M=$ number of data points fitted, and $Y_{\exp }{ }^{2}-Y_{\text {fit }}{ }^{2}=$ difference between squared experimental and fitted EXAFS absorption coefficient $\left(\mathrm{X} \cdot k^{3}\right)$ of the filtered signal for each point (Press et al., 1986). Typical $R$-window range of FT used for back-transform to isolate the first shell is 0.6 to $2.2 \AA$ A. Values in parentheses represent uncertainty for each parameter.

visible at the FT's of these solutions above $\sim 3 \AA$ are likely to be caused by the spectral noise. No second-shell iron atoms $\left(N_{\mathrm{Fe}-\mathrm{Fe}}<\sim 0.1\right)$ could be detected in our dilute solutions at $\mathrm{pH}$ $<2.4$.

At $\mathrm{pH}$ from 2.5 to 3 , and from 12 to 13 , the spectra exhibit an important second shell feature (Figs. $3 \mathrm{a}$ and $3 \mathrm{~b}$ ). This feature is, in part, similar to that of $\alpha-\mathrm{FeOOH}$, and corresponds to several Fe-Fe pairs with distances ranging from 2.9 to $3.5 \AA$. The appearance of Fe-Fe contributions clearly demonstrates the formation of polymeric iron-hydroxide complexes. For an $\mathrm{FeCl}_{3}$ solution at $\mathrm{pH} 2.8$, the second shell feature was successfully fitted using two Fe-Fe subshells with distances of 3.04 and $3.46 \AA$ (Table 4). For iron nitrate solutions at pH 2.8 and 12.7 , the best fits were achieved with three Fe-Fe subshells, at 2.94, $\sim 3.09$, and $3.47 \AA$. These findings are in good agreement with the previous studies by XAFS spectroscopy of the hydrolysis of more concentrated iron chloride and nitrate solutions $(0.1 \leq$ $m_{\mathrm{Fe}} \leq 1.0$ ). Two Fe-Fe distances at 3.01 to 3.05 and 3.44 to $3.47 \AA$ were detected during hydrolysis of $\mathrm{FeCl}_{3}$ (e.g., Combes et al., 1989; Bottero et al., 1994), and at least three distances, at 2.88 to $3.05,3.06$ to 3.14 , and 3.42 to $3.52 \AA$, in the case of $\mathrm{Fe}\left(\mathrm{NO}_{3}\right)_{3}$ hydrolysis (Rose et al., 1997b), in solutions with $\mathrm{OH} / \mathrm{Fe}$ molal ratios $>1.5$. Four different Fe-Fe subshells, with distances ranging from 2.95 to $3.90 \AA$, were reported in a more recent study of iron hydroxide precipitates obtained by hydrolysis of $0.2-\mathrm{mol} / \mathrm{L} \mathrm{FeCl}_{3}$ solutions (Doelsh et al., 2000). Based on these studies and using the analogy with $\mathrm{Fe}$ oxy-hydroxide solids (Manceau and Combes, 1988, and references therein), whose structures consist of $\mathrm{Fe}-\mathrm{O} /(\mathrm{OH})_{6}$ octahedra sharing their faces $\left(R_{\mathrm{Fe}-\mathrm{Fe}}=2.89 \AA\right.$ in hematite $)$, edges $\left(R_{\mathrm{Fe}-\mathrm{Fe}}=2.95-3.30\right.$ $\AA$ in goethite, hematite, akaganeite, lepidocrocite) and/or double corners $\left(R_{\mathrm{Fe}-\mathrm{Fe}}=3.40-3.50 \AA\right.$ in goethite, hematite $)$, the $\mathrm{Fe}-\mathrm{Fe}$ distances derived for the hydrolyzed solutions of the present study can be attributed to polymeric species with edge-

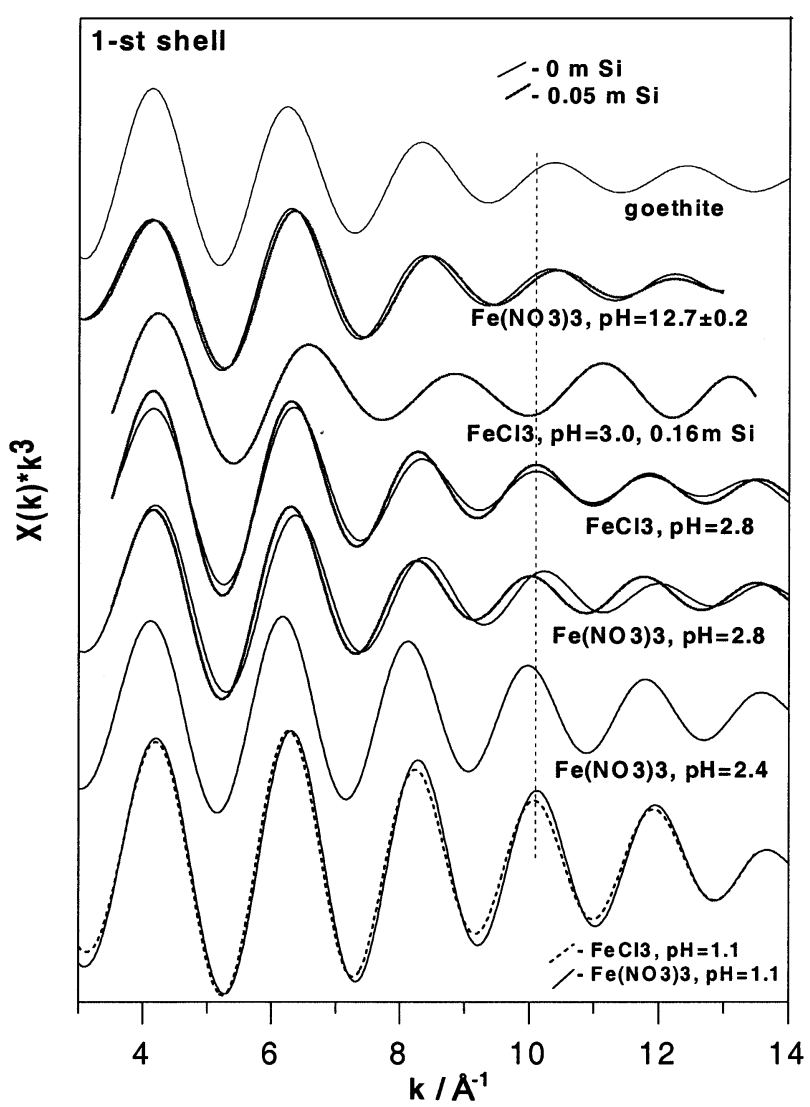

Fig. 4. EXAFS spectra of the first Fe atomic shell of selected 0.01- $m$ Fe nitrate and chloride solutions at the indicated $\mathrm{pH}$, with and without aqueous silica. The vertical line indicates phase shifts with increasing $\mathrm{pH}$ or Si concentration (see text for details). 
Table 4. Structural parameters of the next-nearest atomic shells of iron obtained from fitting Fe K-edge EXAFS spectra of 0.01 molal Fe(III)-nitrate and -chloride solutions with and without aqueous silica. ${ }^{\mathrm{a}}$

\begin{tabular}{|c|c|c|c|c|c|c|}
\hline Solution & $\mathrm{pH}_{20^{\circ} \mathrm{C}}$ & Atomic pair & $\mathrm{R}(\AA)$ & $\mathrm{N}$ (atom) & $\sigma^{2}\left(\AA^{2}\right)$ & $\mathrm{chi}^{2}$ \\
\hline \multicolumn{7}{|l|}{ Si-free solutions } \\
\hline \multirow[t]{3}{*}{$\mathrm{Fe}\left(\mathrm{NO}_{3}\right)_{3}$} & \multirow[t]{3}{*}{2.8} & $\mathrm{Fe}-\mathrm{Fe} 1$ & $2.93(0.03)$ & $0.5(0.2)$ & $0.007(0.003)$ & \multirow[t]{3}{*}{0.25} \\
\hline & & $\mathrm{Fe}-\mathrm{Fe} 2$ & $3.07(0.02)$ & $0.9(0.4)$ & $0.005(0.003)$ & \\
\hline & & $\mathrm{Fe}-\mathrm{Fe} 3$ & $3.46(0.01)$ & $0.5(0.1)$ & $0.004(0.002)$ & \\
\hline \multirow[t]{2}{*}{$\mathrm{FeCl}_{3}$} & \multirow[t]{2}{*}{2.8} & $\mathrm{Fe}-\mathrm{Fe} 1$ & $3.04(0.01)$ & $1.3(0.2)$ & $0.010(0.003)$ & \multirow[t]{2}{*}{0.28} \\
\hline & & $\mathrm{Fe}-\mathrm{Fe} 2$ & $3.46(0.01)$ & $0.5(0.1)$ & $0.005(0.002)$ & \\
\hline \multirow[t]{3}{*}{$\mathrm{Fe}\left(\mathrm{NO}_{3}\right)_{3}$} & \multirow[t]{3}{*}{12.9} & $\mathrm{Fe}-\mathrm{Fe} 1$ & $2.95(0.03)$ & $0.8(0.3)$ & $0.006(0.003)$ & \multirow[t]{3}{*}{0.30} \\
\hline & & $\mathrm{Fe}-\mathrm{Fe} 2$ & $3.12(0.03)$ & $1.2(0.3)$ & $0.006(0.003)$ & \\
\hline & & $\mathrm{Fe}-\mathrm{Fe} 3$ & $3.48(0.04)$ & $0.7(0.3)$ & $0.007(0.002)$ & \\
\hline \multicolumn{7}{|l|}{ Si-bearing solutions } \\
\hline \multirow[t]{2}{*}{$\mathrm{Fe}\left(\mathrm{NO}_{3}\right)_{3}, 0.05-m \mathrm{Si}$} & \multirow[t]{2}{*}{2.8} & $\mathrm{Fe}-\mathrm{Fe}$ & $3.12(0.03)$ & $0.9(0.2)$ & $0.007(0.002)$ & \multirow[t]{2}{*}{0.20} \\
\hline & & $\mathrm{Fe}-\mathrm{Si}$ & $3.18(0.03)$ & $1.5(0.5)$ & $0.007(0.002)$ & \\
\hline \multirow[t]{2}{*}{$\mathrm{FeCl}_{3}, 0.05-m \mathrm{Si}$} & \multirow[t]{2}{*}{2.8} & $\mathrm{Fe}-\mathrm{Fe}$ & $3.12(0.02)$ & $1.3(0.2)$ & $0.007(0.002)$ & \multirow[t]{2}{*}{0.16} \\
\hline & & $\mathrm{Fe}-\mathrm{Si}$ & $3.17(0.03)$ & $2.0(0.5)$ & $0.007(0.002)$ & \\
\hline \multirow[t]{3}{*}{$\mathrm{Fe}\left(\mathrm{NO}_{3}\right)_{3}, 0.05-m \mathrm{Si}$} & \multirow[t]{3}{*}{12.5} & $\mathrm{Fe}-\mathrm{Fe} 1$ & $2.93(0.02)$ & $0.3(0.2)$ & $0.007(0.003)$ & \multirow[t]{3}{*}{0.30} \\
\hline & & $\mathrm{Fe}-\mathrm{Fe} 2$ & $3.11(0.02)$ & $1.5(0.5)$ & $0.007(0.003)$ & \\
\hline & & $\pm \mathrm{Fe}-\mathrm{Si}$ & $3.17(0.03)$ & $2.0(1.0)$ & $0.007 \mathrm{f}$ & \\
\hline
\end{tabular}

${ }^{a}$ See footnotes for Tables 1 and 3.

Typical $R$-window range of FT used for back-transform to isolate the next-nearest shells is 2.2 to $3.5 \AA$ for Si-free solutions, and 2.15 to $3.3 \AA$ for Si-bearing solutions.

and double corner-sharing $\mathrm{Fe}-\mathrm{O}_{6}$ octahedra. Although the 2.94 $\pm 0.01 \AA$ distance found for our nitrate solutions is close to that corresponding to Fe-Fe face-sharing in hematite $(2.89 \AA)$, the formation of edge-sharing structures during Fe hydrolysis at ambient temperature is unlikely (e.g., Combes et al., 1989; Jolivet et al., 1994). Hematite-like structures usually form from ferric gels at later stages of hydrolysis or after long aging times and at elevated temperatures that favors dehydration (e.g., Schwertmann and Taylor, 1989; Combes et al., 1990). The structures found in our dilute solutions are similar to those of $\mathrm{Al}(\mathrm{III}), \mathrm{Ga}(\mathrm{III})$, and $\mathrm{Cr}(\mathrm{III})$ hydroxide polymeric species formed in concentrated solutions $(0.2-1.0 \mathrm{~m})$ during the hydrolysis of nitrate or chloride salts of these metals (Jolivet et al., 1994; Michot et al., 2000; Pokrovski et al., 2002b). Note that beyond the first Fe shells, all hydrolyzed solutions investigated in this study were reasonably modeled using two to three Fe-Fe contributions, in accordance to the degree of freedom for our filtered second shell spectra which ranges between 5 and 9 (Stern, 1993). The addition of a fourth Fe-Fe shell (for example at $\sim 3.3$ or $3.9 \AA$ ) led to highly correlated and often unreasonable Debye-Waller factors and coordination numbers and decreased significantly the goodness of fit. Consequently, taking into account the signal-to-noise ratio and $k$-range of the spectra of the dilute solutions investigated in this study, a two- or three-shell model was kept throughout the analysis of Fe hydrolysis.

\subsection{EXAFS Analysis of Silica-Bearing Solutions}

\subsubsection{First atomic shell}

In the presence of 0.05- $m$ aqueous silica in strongly acid $(\mathrm{pH}$ $<2-2.5)$ and basic $(\mathrm{pH}>12)$ solutions, no changes in the first coordination shell of iron were detected in comparison with their Si-free analogs (Table 3), which is also in agreement with the XANES analysis (see above). In contrast, in the intermediate $\mathrm{pH}$ region $(2.7<\mathrm{pH}<3)$, $\mathrm{Fe}-\mathrm{O}_{6}$ distances in $0.05-m \mathrm{Si}$ chloride and nitrate solutions are distinctly longer than in their Si-free counterparts (2.00 instead of $1.97 \AA$, see Table 3 and Fig. 4) and close to those in more acidic solutions. This is also in line with the XANES analysis and can be interpreted by a partial destruction of the relatively short Fe-O-Fe linkages between $\mathrm{FeO}_{6}$ octahedra and formation of longer $\mathrm{Fe}-\mathrm{OH}$ or $\mathrm{Fe}-\mathrm{O}-\mathrm{Si}$ bonds.

In a more concentrated $\mathrm{Si}$ solution $(0.16-\mathrm{m} \mathrm{Si})$ at $\mathrm{pH} 3$, the EXAFS spectrum is distinctly different, exhibiting important phase shifts and amplitude changes compared to the spectra of less concentrated Si solutions at similar pH (Figs. 4 and 5). Modeling of this spectrum is consistent with the presence of two distinct sets of Fe-O distances: $\sim 1.84 \AA(N=1)$ and 1.99 $\AA(N=4-5)$ (Table 3$)$. The shorter Fe-O distance is very close to those found in tetrahedral sites of $\mathrm{Fe}^{3+}$ in $\mathrm{Li}(\mathrm{Al}, \mathrm{Fe}) \mathrm{O}_{2}$ (Table 1) and Fe(III)-bearing micas (e.g., Dyar et al., 2001; Giuli et al., 2001). The derived Fe-O distances and coordination numbers imply the presence of $\sim 20 \% \mathrm{Fe}$ in a tetrahedral coordination, probably substituting for $\mathrm{Si}$ in the tetrahedral framework of the silica polymers formed in this solution. Note that the percentage of ${ }^{[4]} \mathrm{Fe}$ deduced from the EXAFS analysis is in excellent agreement with that derived from the pre-edge data (see above).

\subsubsection{Second and third atomic shells}

In the spectra of acid solutions in the presence of $0.05-m \mathrm{Si}$ $(\mathrm{pH}<2.4)$, no second-shell $\mathrm{Fe}-\mathrm{Fe}$ or $\mathrm{Fe}-\mathrm{Si}$ contributions were detected in the limit of the spectral resolution $\left(N_{\mathrm{Fe}-\mathrm{Fe}}<\sim 0.1\right.$; $N_{\mathrm{Fe}-\mathrm{Si}}<\sim 0.5$ atoms).

At pH 2.8 in contrast, important changes occur in the spectra of both $0.01-m$ ferric nitrate and chloride solutions in the presence of $0.05-m$ aqueous silica. This is manifested by the disappearance, in the total EXAFS spectrum, of the feature at $\sim 7.5-8 \AA^{-1}$ which corresponded to the Fe-Fe contributions in $\mathrm{Si}$-free solutions, and by distinct phase shifts in the region 7 to 

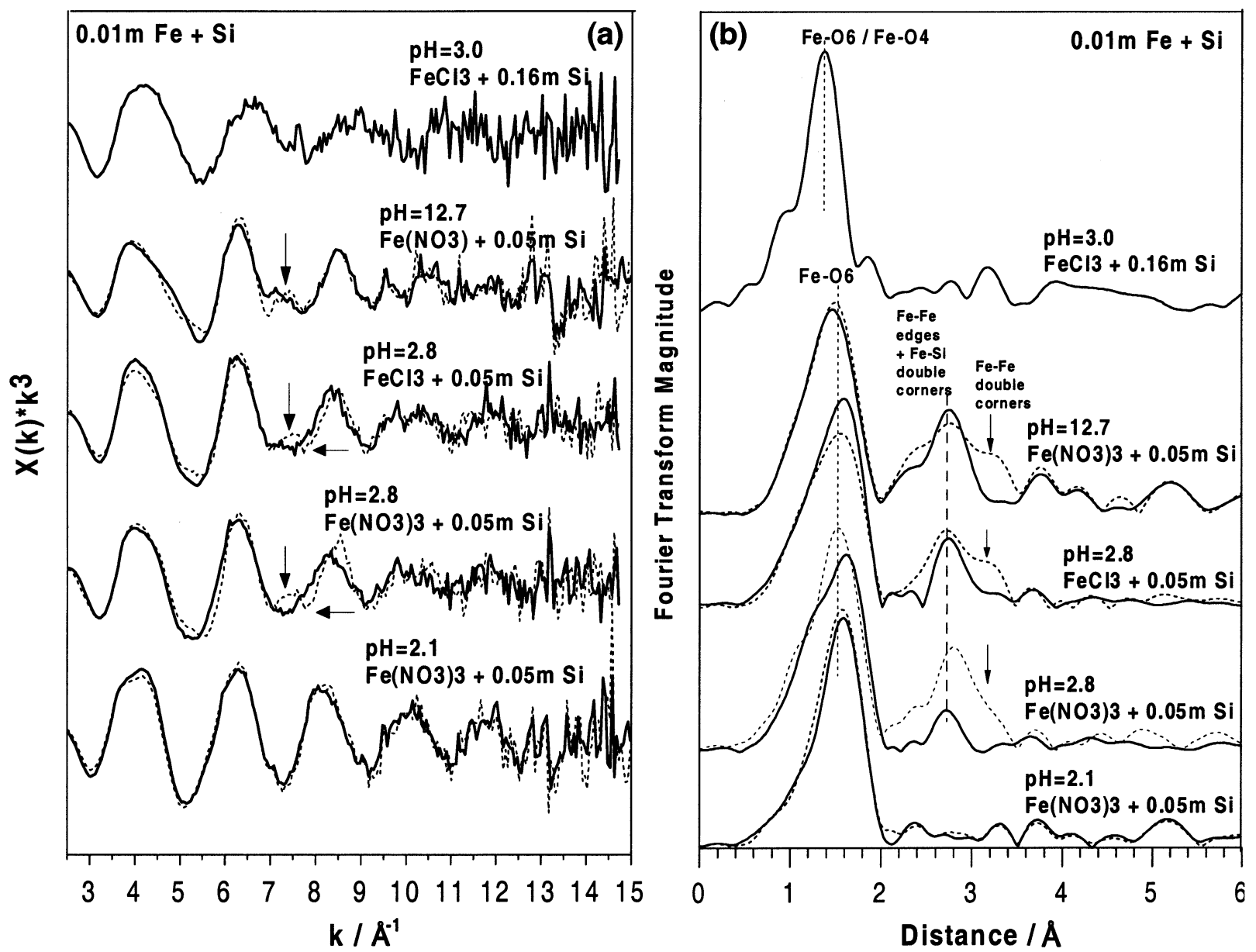

Fig. 5. $k^{3}$-weighted EXAFS spectra at the Fe-K edge of 0.01- $m$ Fe nitrate and chloride solutions in the presence of aqueous silica at different $\mathrm{pH}$ (a); and their Fourier Transforms (not corrected for phase shift) (b). Solid curves = Si-bearing solutions with indicated concentrations and $\mathrm{pH}$; dashed curves = spectra of the corresponding Si-free solutions at the same $\mathrm{pH}$ (see also Fig. 3). The arrows indicate changes in the presence of aqueous silica: phase shifts (a); suppression of the double-corner Fe-Fe contributions in the second Fe atomic shell (b). The vertical lines on (b) stand for octahedral or tetrahedral first shell coordination of $\mathrm{Fe}$, and $\mathrm{Fe}-\mathrm{Fe}$ edge and $\mathrm{Fe}-\mathrm{Si}$ double corner linkages in the second shell of iron in its silicate complexes.

$9 \AA^{-1}$ (Fig. 5a). The contributions from the Fe-Fe edges at $\sim 2.95 \AA$ for nitrate solutions, and Fe-Fe double-corner linkages for both nitrate and chloride solutions, apparent in the RDF's of the Si-free samples at these $\mathrm{pH}$ values, disappear in the presence of silica (Fig. 5b). The filtered second shell signal exhibits an important amplitude decrease and phase shift in the presence of silica (Fig. 6). These observations strongly suggest a destruction of the Fe-Fe linkages of iron hydroxide polymers, and the entering of $\mathrm{Si}$ in the second coordination shell of $\mathrm{Fe}$. The analysis of the iron second shell for these samples was performed using either two $\mathrm{Fe}-\mathrm{Fe}$ subshells or one $\mathrm{Fe}-\mathrm{Fe}+$ one $\mathrm{Fe}-\mathrm{Si}$ subshell. Figure 7 shows such fits for Fe nitrate and chloride solutions at $\mathrm{pH} 2.8$ with $0.05-\mathrm{m} \mathrm{Si}$. It can be seen in this figure that the presence of iron atoms only cannot account for the observed second shell signal. Including light neighbors like oxygens or $\mathrm{Cl} / \mathrm{NO}_{3}$ do not affect the fit; adding a third $\mathrm{Fe}-\mathrm{Fe}$ subshell resulted in less robust models, yielding highly correlated and unreasonable $N$ and $\sigma^{2}$ values. In contrast, significant good-quality fits were obtained for both solutions using 0.9 to $1.3 \mathrm{Fe}$ atoms at $3.12 \pm 0.03 \AA$, and $\sim 2 \pm 0.5 \mathrm{Si}$ atoms at $3.18 \pm 0.03 \AA$ (Fig. 7, Table 4). The uncertainties on these $N$ and $R$ values stem mostly from possible variations of the $\Delta E_{0}$ parameter ( $\pm 2 \mathrm{eV}$, see section 2.2). Because $\mathrm{Fe}-\mathrm{Fe}$ and $\mathrm{Fe}-\mathrm{Si}$ individual electronic waves are shifted by $>\pi / 2$ and thus are almost out of phase, the amplitude of the resulting spectrum for the second shell is quite sensitive to the value chosen for $\Delta E_{0}$. Nevertheless, fits of the Fe-Fe/Si contributions at $\mathrm{pH} 2.8$ were robust and always converged to the parameters reported in Table 4 whatever the starting values of $R, N$, and $\Delta E_{0}$. These results confirm quantitatively the observations of RDF's of these solutions, which indicate the destruction of $\mathrm{Fe}-\mathrm{Fe}$ edge and double-corner bonds in the iron polymeric species in the presence of Si (Fig. 5b).

At $\mathrm{pH} 12.7$ in the presence of $0.05-\mathrm{m} \mathrm{Si}$, similar changes in the EXAFS spectrum were observed (Figs. 5 and 6). The suppression of $\mathrm{Fe}-\mathrm{Fe}$ edge and corner contributions is apparent on the Fourier Transform (Fig. 5b). A fit of the second-shell signal confirms these observations, yielding two Fe-Fe edge 


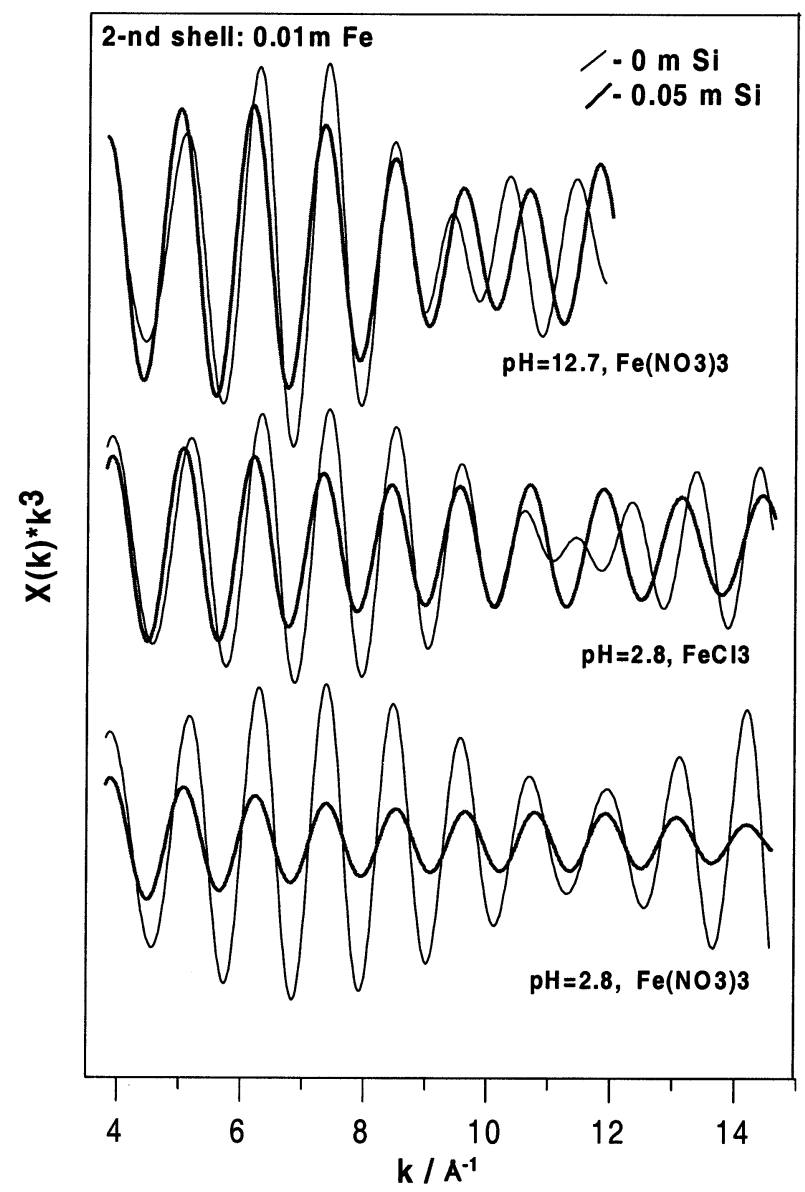

Fig. 6. Comparison of second-shell filtered EXAFS signal of Si-free and Si-bearing 0.01- $m$ Fe solutions. Note important amplitude decrease and phase shifts in the presence of $\mathrm{Si}$, suggesting a partial destruction of $\mathrm{Fe}-\mathrm{Fe}$ bonds and formation of $\mathrm{Fe}-\mathrm{Si}$ linkages.

contributions at 2.93 and $3.11 \AA$ (Table 4). The amplitude decrease of the second shell Fe-Fe signal was, however, much weaker than for less hydrolyzed solutions at acid pH (Fig. 6). Consequently, fits were less sensitive to the presence of silicon. It was found that addition of $2 \pm 1 \mathrm{Si}$ atoms at $3.17 \AA$ improves only slightly the fit quality. This is in agreement with previous EXAFS studies of $\mathrm{Fe}$ hydroxide precipitates formed in the presence of Si (Doelsh et al., 2000), and hydrous iron silicate scale deposits (Manceau et al., 1995) that failed to detect the light $\mathrm{Si}$ in the second iron coordination shell dominated by $\mathrm{Fe}-\mathrm{Fe}$ contributions. At earlier hydrolysis stages $(\mathrm{pH}<3.0)$ of our experimental solutions of low $\mathrm{Fe}$ concentration, the $\mathrm{Fe}-\mathrm{Fe}$ contributions to the EXAFS signal are significantly lower and thus allow accurate detection of light silicon atoms in the second shell.

With increasing Si concentration (0.16- $m \mathrm{Si}, \mathrm{pH}=3)$, Fe-Fe second shell contributions vanish indicating the almost complete destruction of iron polymers. The detection of Si was also impossible, probably because of an important disorder associated with various ${ }^{[4]} \mathrm{Fe}-\mathrm{O}-\mathrm{Si}$ and ${ }^{[6]} \mathrm{Fe}-\mathrm{O}-\mathrm{Si}$ contributions. More measurements in Si-rich solutions are required to distinguish between these different linkages.

\section{DISCUSSION}

\subsection{Iron Hydrolysis and Polymerization in Dilute Solutions}

The results of this study demonstrate that the $\mathrm{Fe}^{3+}$ cation rapidly hydrolyses in dilute chloride and nitrate aqueous solutions via formation of $\mathrm{Fe}$ oxy-hydroxide polynuclear species composed of $\mathrm{Fe}\left(\mathrm{O} / \mathrm{OH} / \mathrm{H}_{2} \mathrm{O}\right)_{6}$ octahedra linked together by their edges and double corners. This is in good agreement with previous XAFS studies of Fe hydrolysis in concentrated solutions $(>0.1-m \mathrm{Fe})$ that have shown the formation of large $\mathrm{Fe}$ polymers in chloride and nitrate solutions with increasing $\mathrm{OH} / \mathrm{Fe}$ ratios or aging time (e.g., Combes et al., 1989, 1990; Bottero et al., 1994; Rose et al., 1997b). The number of edge (2.90-3.05 $\AA$ ) and double-corner (3.40-3.50 ̊) linkages derived in those studies increase, respectively, from 1 to 3.5 and from 1 to 2 in solutions with $\mathrm{OH} / \mathrm{Fe}$ ratios $>1.5(2<\mathrm{pH}<5)$, suggesting the presence of large $\mathrm{Fe}$ oxy-hydroxide entities (e.g., "Fe $\mathrm{Fe}_{24}$," Bottero et al., 1994). Such species are regarded as precursors for goethite, akaganeite or hematite (depending on solution composition, temperature and time of aging). In the more dilute solutions of the present study, the number of edgeand corner-sharing neighbors at $\mathrm{pH}$ of $\sim 2.8$ is consistent with the formation of smaller Fe polymers, most likely a mixture of dimers, trimers and tetramers. At basic $\mathrm{pH}(\mathrm{OH} / \mathrm{Fe}>5)$, the Fe-Fe coordination numbers $\left(N_{\text {edge }}=2.0, N_{\text {corner }}=0.7\right.$; Table 4) correspond to tetramers or/and bigger polymeric species (e.g., " $\mathrm{Fe}_{24}$ "), in agreement with previous studies. The schematic structures of the main hydroxide polymers likely to form during $\mathrm{Fe}(\mathrm{III})$ hydrolysis are presented in Figure 8.

The results on Fe-hydrolysis obtained in this study can be compared with speciation calculations using the available stability constants for the iron dimer, $\mathrm{Fe}_{2}(\mathrm{OH})_{2}{ }^{4+}$, and trimer, $\mathrm{Fe}_{3}(\mathrm{OH})_{4}{ }^{5+}$, obtained from potentiometric measurements in dilute Fe nitrate or chloride solutions (e.g., Baes and Mesmer, 1976; Martell et al., 1998, and references therein). The distribution of $\mathrm{Fe}$ hydroxide species in a $0.01-m \mathrm{Fe}$ (III) nitrate solution at $25^{\circ} \mathrm{C}$ and a $0.15-\mathrm{mol} / \mathrm{L}$ ionic strength is shown as a function of $\mathrm{pH}$ in Figure $9 \mathrm{a}$. At $\mathrm{pH}<2.4$, calculations predict $<20 \%$ of total $\mathrm{Fe}$ is present as dimers, and $<5 \%$ as trimers, which corresponds to $\sim 0.2 \mathrm{Fe}$ atoms in the second Fe shell. This is close to the detection limit of $\mathrm{Fe}-\mathrm{Fe}$ second neighbors of our EXAFS spectra. At higher $\mathrm{pH}(2.6<\mathrm{pH}<3.0)$, calculations indicate that the dimer and trimer account for $\sim 20$ to $30 \%$ of total Fe each. This corresponds to $N_{\text {edge }}=\sim 0.4$ to 0.5 and $N_{\text {corner }}=\sim 0.3 \mathrm{Fe}$ atoms, assuming an edge-sharing dimer and a double-corner trimer (Bottero et al., 1994; Jolivet et al., 1994). Our EXAFS analysis yields significantly higher coordination numbers at these $\mathrm{pH}$ values, confirming the formation of bigger Fe polymers, likely tetramers (Fig. 8). Note that tetrameric species with edge and double-corner linkages were shown to form during $\mathrm{Cr}^{3+}$ and $\mathrm{Ga}^{3+}$ hydrolysis; they are also considered as precursors for the nucleation of $\mathrm{Al}$ and $\mathrm{Fe}$ (III) oxy-hydroxide phases (Jolivet et al., 1994, and references therein; Michot et al., 2000). The very high lability of $\mathrm{Fe}^{3+}$ in comparison to $\mathrm{Al}^{3+}$ or $\mathrm{Cr}^{3+}$ makes it difficult to stabilize small $\mathrm{Fe}$ polymers in supersaturated solution in the absence of strongly complexing ligands (Jolivet et al., 1994) which can explain the absence of thermodynamic data for Fe-tetramers 

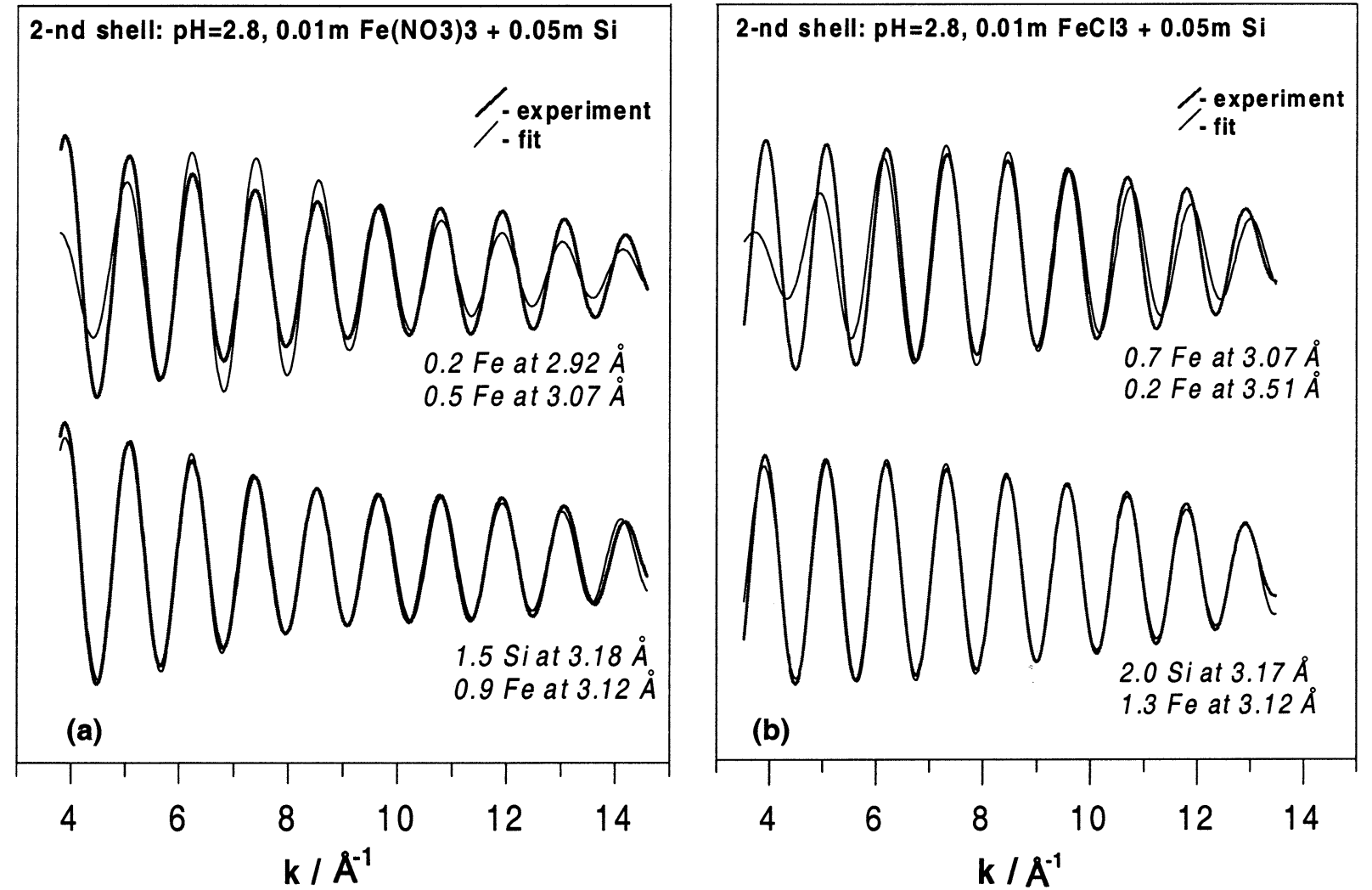

Fig. 7. Examples of EXAFS fits of the filtered second shell signal of 0.01- $m$ ferric nitrate (a) and chloride (b) solutions at $\mathrm{pH} 2.8$ in the presence of $0.05-m$ Si. It can be seen that Fe-Fe contributions only cannot account for the observed spectrum. Including a Fe-Si shell yields robust good-quality fits in a wide $k$-range (see text for details).

and the "Fe ${ }_{24}$ " polycation. ${ }^{1}$ Consequently, the equilibrium calculations presented here give a simplified image of iron speciation especially at $\mathrm{pH}>3-4$, which is likely dominated by tetrameric and/or bigger species.

\subsection{Iron-Chloride Complexing}

The presence of chlorine neighbors was not detected in the first and second $\mathrm{Fe}$ atomic shell in hydrolyzed $0.01-m \mathrm{FeCl}_{3}$ solution at $\mathrm{pH}$ 2.8. This is in agreement with equilibrium calculations carried out using the available stability constants for $\mathrm{Fe}(\mathrm{III})$ chloride species (taken from the compilation of Tagirov et al., 2000), suggesting that only $6 \%$ of total Fe should be complexed in the form of $\mathrm{FeCl}^{2+}$ and $\mathrm{FeCl}_{2}{ }^{+}$species in this solution. In strongly acid non-hydrolyzed solution $(\mathrm{pH} \sim 1$, 0.1- $m \mathrm{Cl}^{-}, 0.01-m \mathrm{FeCl}_{3}$ ), less than $0.3 \mathrm{Cl}$ atoms could be detected in the Fe first shell from analysis of its EXAFS spectrum. Speciation calculations for this solution composition indicate that $\mathrm{FeCl}^{2+}$ and $\mathrm{FeCl}_{2}{ }^{+}$represent respectively $\sim 40$ and $\sim 10 \%$ of total $\mathrm{Fe}$. This corresponds to an average $\mathrm{Fe}-\mathrm{Cl}$ coordination number of 0.6 , if one assumes inner-sphere complexation. The lower first shell coordination number obtained in

1 The value of the first-order rate coefficient for the exchange of water molecules from the bulk solution into the inner coordination sphere of the hexacoordinated aquo ion is $1.6 \times 10^{2}, 1.3$ and $2.4 \times 10^{-6} \mathrm{~s}^{-1}$ for $\mathrm{Fe}^{3+}, \mathrm{Al}^{3+}$ and $\mathrm{Cr}^{3+}$, respectively (Merbach and Akitt, 1990). this study $\left(N_{\mathrm{Fe}-\mathrm{Cl}} \sim 0.3\right.$, Table 3$)$ suggests a portion of $\mathrm{Fe}-\mathrm{Cl}$ species may be in the form of outer-sphere complexes which could not be detected by EXAFS analysis in this study. Thus, the presence of $\mathrm{Cl}$ atoms weakly bonded to $\mathrm{Fe}$ hydroxide species in outer coordination shells during iron hydrolysis cannot be completely excluded. More ordered second shell $\mathrm{Fe}-\mathrm{Fe}$ structures observed in this study at $\mathrm{pH} 2.8$ for $0.01-m$ chloride (two Fe-Fe subshells) compared to nitrate (three $\mathrm{Fe}-\mathrm{Fe}$ subshells) solutions, imply that chloride can probably intervene in $\mathrm{Fe}$ hydrolysis in dilute solutions, as it was suggested for Cl-rich solutions (0.2-1.0-m Cl; Combes et al., 1989; Doelsh et al., 2000). However, the structural role of $\mathrm{Cl}^{-}$during the hydrolysis of dilute $\mathrm{Fe}$ (III)-chloride solutions remains unclear. At ambient temperature, the negatively charged $\mathrm{Cl}^{-}$could weakly interact with the outer shells of positively charged $\mathrm{Fe}$ polymeric oxy-hydroxide species and affect polymerization/ nucleation kinetics. However, as it is demonstrated in this study, the role of $\mathrm{Cl}^{-}$in $\mathrm{Fe}$ hydrolysis in dilute solutions is negligible as compared to that of silica.

\subsection{Structure and Stoichiometry of Fe-Si Aqueous Complexes}

XAFS measurements reported in this study unambiguously demonstrate that aqueous silica inhibits $\mathrm{Fe}^{3+}$ hydrolysis via formation of stable complexes with polymeric ferric oxy-hydroxide species. $\mathrm{Fe}-\mathrm{Si}$ and $\mathrm{Fe}-\mathrm{Fe}$ distances and coordination 

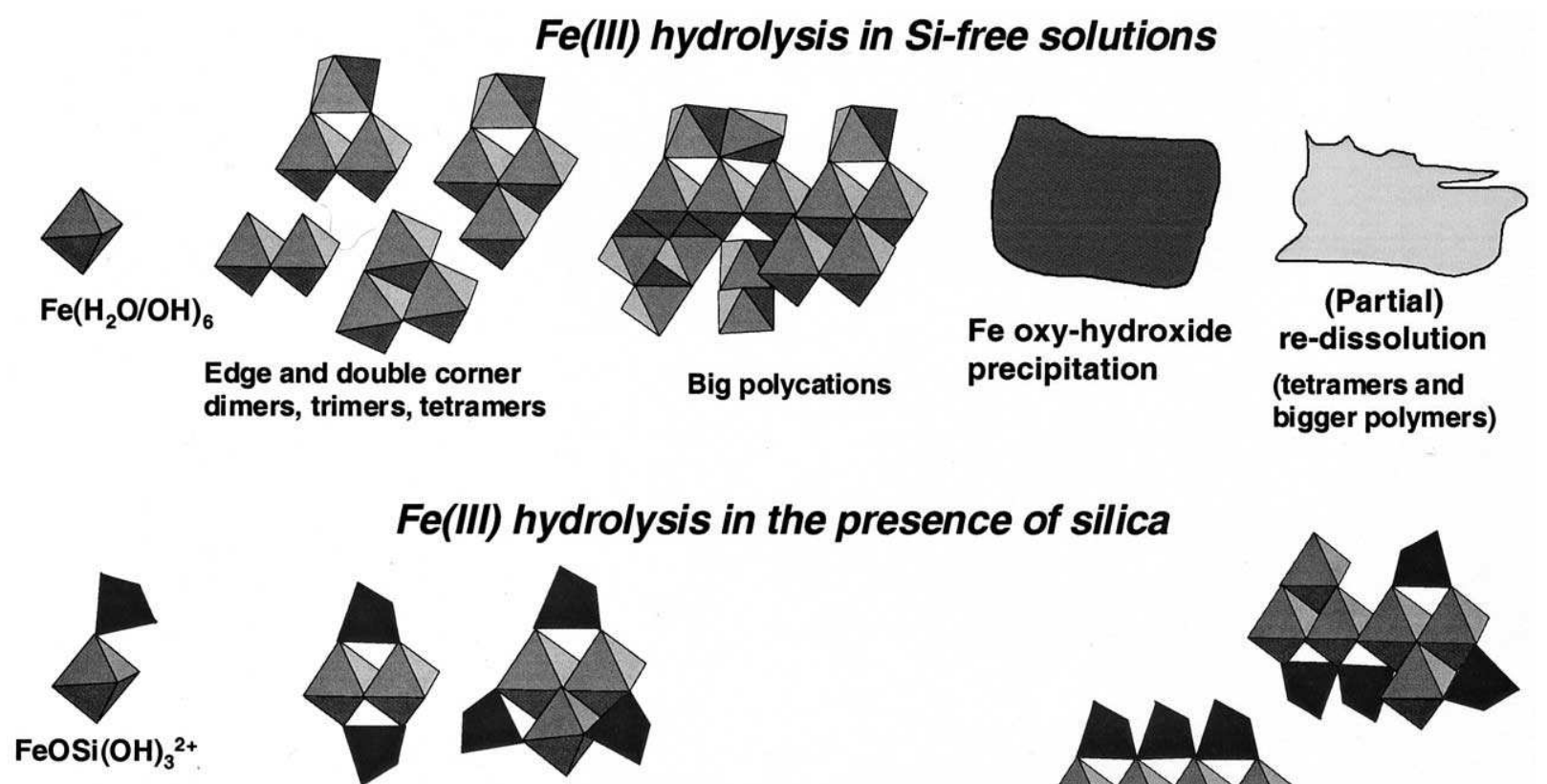

\section{$\mathrm{Fe}(\mathrm{III})$ hydrolysis in the presence of silica}

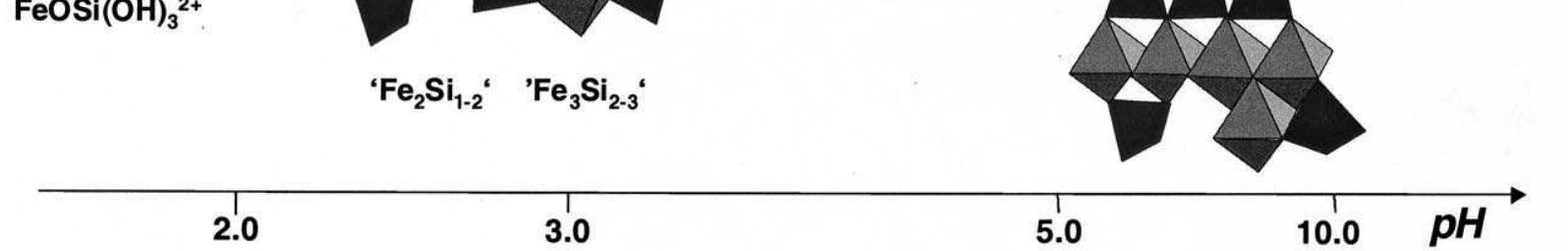

Fig. 8. Schematic illustration of Fe(III) hydrolysis in Si-free aqueous solution, and structures of Fe-Si complexes proposed in this study for moderately concentrated Si-solutions. Octahedra represent the first $\mathrm{Fe}\left(\mathrm{O} / \mathrm{OH} / \mathrm{H}_{2} \mathrm{O}\right)_{6}$ atomic shell; tetrahedra stand for the silicate moieties $\mathrm{Si}(\mathrm{O} / \mathrm{OH})_{4}$ of monomeric silicic acid or silica polymers.

numbers derived in this study indicate that $\mathrm{SiO}_{4}$-tetrahedra substitute for double-corner $\mathrm{FeO}_{6}$-octahedra in the $\mathrm{Fe}(\mathrm{III})$ polymers. The iron-silicon distance of $3.18 \AA$ found in both nitrate and chloride solutions is close to those for $\mathrm{Fe}-\mathrm{As}$ and $\mathrm{Fe}-\mathrm{Se}$ in ${ }^{2} \mathrm{C}$-type surface complexes formed by slightly bigger arsenate and selenate anions with hydrous ferric oxides $(\sim 3.25$ $\AA$ A, Manceau and Charlet, 1994; Manceau, 1995; Waychunas et al., 1993, 1995), and those for Fe-P found in Fe(III) phosphate minerals and aqueous solution $(\sim 3.20 \AA$, Rose et al., 1996, 1997a). The iron-iron coordination numbers corresponding to the $\mathrm{Fe}-\mathrm{Fe}$ edge linkages are affected only slightly in the presence of aqueous silica both at acid and basic $\mathrm{pH}$ (Table 4). This suggests that at the early stages of hydrolysis, after the $\mathrm{Fe}-\mathrm{Fe}$ dimer formation (Jolivet et al., 1994), aqueous silica is not capable of destroying these bonds significantly. The iron-iron edge distances in the silicate complexes found in this study (3.12 $\AA$ ) are the same in both nitrate and chloride solutions at $\mathrm{pH} 2.8$, suggesting that the edge-linked Fe polymers accommodate silica tetrahedra in a very similar way, independently of the nature of the ligand $\left(\mathrm{Cl}^{-}\right.$versus $\left.\mathrm{NO}_{3}{ }^{-}\right)$. This confirms that neither chloride nor nitrate influence significantly Fe-Si interactions in dilute solutions typical of natural waters.

The numbers of $\mathrm{Fe}$ and $\mathrm{Si}$ neighbors around iron in the silicate complexes formed at acid $\mathrm{pH}\left(N_{\mathrm{Fe}-\mathrm{Fe}}=0.9-1.3 ; N_{\mathrm{Fe}-\mathrm{Si}}\right.$ $=1.0-2.0)$ is consistent with stoichiometries $\mathrm{Fe}_{2} \mathrm{Si}_{1-2}$ and $\mathrm{Fe}_{3} \mathrm{Si}_{2-3}$, corresponding to a mixture of $\mathrm{Fe}-\mathrm{Fe}$ dimers and planar trimers linked to one to three silicate anions by their free double corners (Fig. 8). At basic pH, the Fe-Fe and Fe-Si coordination numbers found in this study imply that more polymerized Fe-Fe species, such as edge-sharing tetramers or bigger, are likely to form similar structures with silica. Note that the speciation of silica in $0.05-m$ Si solutions investigated in the present work is dominated by polymeric species $(\sim 80 \%$ of total $\mathrm{Si}$ ) at acid $\mathrm{pH}$ and by monomeric silicate anions $(>90 \%$ of total $\mathrm{Si}$ ) at basic $\mathrm{pH}$ (see section 2.1). Nevertheless, the structural position of silicon atoms in the Fe-Si complexes appears to be similar at both acid and basic $\mathrm{pH}$. This might reflect the preferential interaction of hydrolyzed Fe-polymers with monomeric $\mathrm{Si}(\mathrm{OH})_{4}$. Indeed, reactions with big silicate polymers are likely to be hampered by slow kinetics and steric constraints (e.g., Swaddle, 2001). However, it cannot be excluded that $\mathrm{Fe}$ might interact with certain configurations of silicic acid polymers in acid solution. The structures of $\mathrm{Fe}-\mathrm{Si}$ complexes proposed in this study are summarized in Figure 8.

By analogy with other tetrahedral anions like arsenate, selenate or phosphate, silicate can be expected to form also other types of bonds with Fe-octahedra, such as edge (type ${ }^{1} \mathrm{E}$, $R_{\mathrm{Fe}-\mathrm{Si}} \sim 2.8-2.9 \AA$ ) and single-corner (type ${ }^{1} \mathrm{C}, R_{\mathrm{Fe}-\mathrm{Si}} \sim$ 3.4-3.6 ̊) linkages (e.g., see Manceau and Charlet, 1994; Manceau, 1995, for the linkage terminology). Nevertheless, none of these contributions was detected in this study. The ${ }^{1}$ E-linkages are not known in $\mathrm{Fe}(\mathrm{III})$ silicate and phosphate minerals. Thus, the edge-edge linkages between $\mathrm{FeO}_{6}$ and $\mathrm{SiO}_{4}$ are supposed to be negligible in solution, at least at the conditions of the present work. The existence of ${ }^{1} \mathrm{C}$ bonds in the Si-rich solutions investigated in this study, however, cannot be 

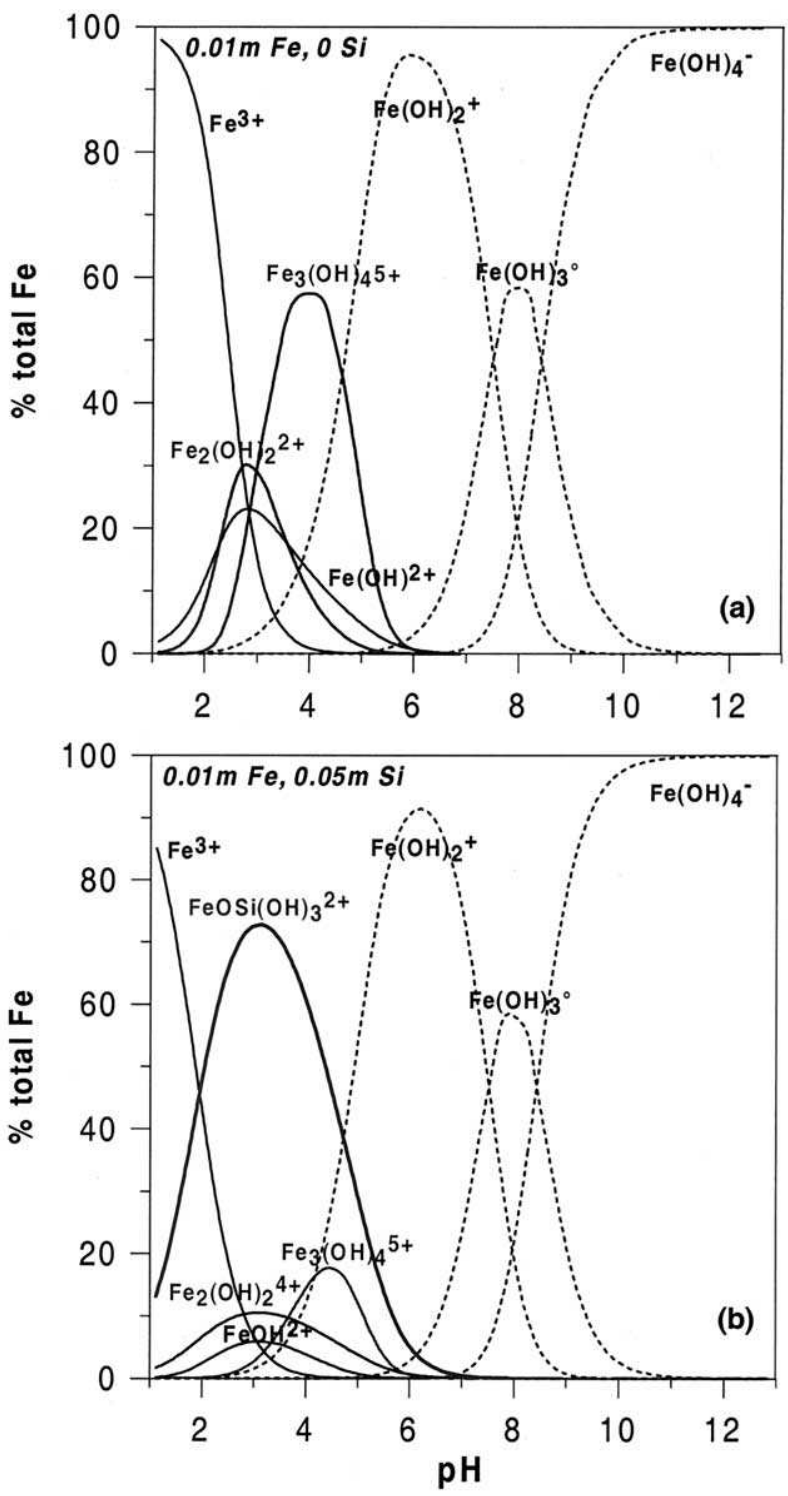

Fig. 9. Predicted iron speciation in a 0.01- $m$ ferric nitrate Si-free solution (a), and in the presence of $0.05-m$ monomeric silica (b) at $25^{\circ} \mathrm{C}$ as a function of solution $\mathrm{pH}$. Calculations were performed using the stability constants for $\mathrm{Fe}$ hydroxide species reported by Baes and Mesmer (1976), and that for the iron-silica complex as the average value from Weber and Stumm (1965), Olson and O'Melia (1973), and Reardon (1979): $\mathrm{Fe}^{3+}+\mathrm{Si}(\mathrm{OH})_{4}(\mathrm{aq})=\mathrm{FeOSi}(\mathrm{OH})_{3}{ }^{2+}+\mathrm{H}^{+}$, $\log _{10} \mathrm{~K}\left(25^{\circ} \mathrm{C}, I=0\right)=0.03 \pm 0.10$. Ionic strength was fixed at 0.15 , and the activity coefficients of aqueous species were approximated by the extended Debye-Hückel equation with $̊=4.5 \AA$ for all charged species. Note that because of the lack of stability constants for iron oligomers bigger than trimers, this diagram represents a simplified image of the iron speciation at $\mathrm{pH}>3-4$. Consequently, the monomeric species at $\mathrm{pH}>4$ (dashed lines) are likely not dominant, and they are shown only for consistency with the calculations.

ruled out. Because of the expected higher degree of freedom associated with such single-corner bonds, their detection by EXAFS spectroscopy, which is very sensitive to disorder, is likely to be difficult. This is confirmed by the fact that no Si could be detected around the iron atom in the present study in a Si-rich solution $(0.16-m \mathrm{Si})$ at $\mathrm{pH}$ 3. The presence of single corner $\mathrm{Fe}-\mathrm{O}-\mathrm{Si}$ bonds is also expected in the monomer complex $\mathrm{FeOSi}(\mathrm{OH})_{3}{ }^{2+}$ reported in acid solutions (Weber and Stumm, 1965; Olson and O'Melia, 1973; Reardon, 1979). Equilibrium calculations using the stability constant for this species derived from the studies cited above suggest that this complex should account for $50 \pm 10 \%$ of total $\mathrm{Fe}$ at $\mathrm{pH} \sim 2.1$ in the presence of $0.05-m \mathrm{Si}(\mathrm{OH})_{4}$ (Fig. 9b). This percentage corresponds to an average number of Si neighbors of $\sim 0.5$ in the second coordination sphere of $\mathrm{Fe}$ at this $\mathrm{pH}$. However, no Si neighbors could be found in the spectrum of a 0.05- $m$ total Si solution at $\mathrm{pH} 2.1$, in which silica was partially polymerized (see above). This might reflect both the difficulties to detect, by EXAFS spectroscopy, the light silicon in the disordered second shell environment of iron, and the lower affinity of $\mathrm{Fe}^{3+}$ cation for polymeric silicate species than for monomeric silicic acid (see above). More measurements at different $\mathrm{Si}$ concentrations are needed to confirm this hypothesis.

\section{CONCLUDING REMARKS}

The results of this study demonstrate that aqueous silica affects the hydrolysis of $\mathrm{Fe}(\mathrm{III})$ in dilute solution via the formation of iron silicate aqueous complexes. In these structures, silica substitutes for double-corner $\mathrm{FeO}_{6}$-octahedra in iron oxy-hydroxide polymeric complexes existing at the early stages of $\mathrm{Fe}$ (III) hydrolysis, likely by forming ${ }^{2} \mathrm{C}$-type (double corner) complexes with small $\mathrm{Fe}$ oxy-hydroxide polymers whose structure consists of $\mathrm{FeO}_{6}$-octahedra linked together by common edges. To our knowledge, this is the first quantitative evidence of the silica atomic environment in ferric silicate aqueous complexes.

The formation of soluble Fe-Si complexes delays the nucleation and growth of solid ferric oxy-hydroxides from aqueous solution. The significant silica concentrations found in these minerals in nature (e.g., Carlson and Schwertmann, 1981; Konhauser and Ferris, 1996) are likely to be a consequence of the aqueous $\mathrm{Fe}-\mathrm{Si}$ complexing. However, the effect of silica on $\mathrm{Fe}(\mathrm{III})$ hydrolysis is significantly weaker than on $\mathrm{Al}^{3+}$ or $\mathrm{Ga}^{3+}$ hydrolysis. Due to the high affinity of $\mathrm{Al}$ and $\mathrm{Ga}$ for the tetrahedral coordination, these elements form much stronger covalent-bonded silicate complexes in which the metal is tetracoordinated even at acid $\mathrm{pH}$ and low silica concentrations $(<0.01-m \mathrm{Si})$ (Pokrovski et al., 2002b). Ferric iron, in contrast, keeps an octahedral environment at moderate Si concentrations, and takes a tetrahedral coordination only in solutions highly enriched in silica $(>0.1-m \mathrm{Si})$, in which $\mathrm{Fe}^{3+}$ may substitute for $\mathrm{Si}$ in the Si-polymer network. The observation, in hightemperature hydrothermal and metamorphic environments, of micas and amphiboles having significant proportions of $\mathrm{Fe}^{3+}$ in tetrahedral coordination (e.g., Dyar et al., 2001; Giuli et al., 2001) could thus be indicative of high silica activities during the formation of such minerals. In near-surface conditions, which are characterized by much lower aqueous silica activities, $\mathrm{Fe}^{3+}$ remains essentially hexa-coordinated in low-temperature oxy-hydroxides and clays (e.g., Sherman and Vergo, 1988; Manceau et al., 1998).

The geometry and structure of the silicate complexes formed at the surfaces of iron oxy-hydroxide minerals and colloids are expected to be similar to those found for the Fe-Si aqueous solutions investigated in this study. Via its linking to the free 
corners of $\mathrm{FeO}_{6}$-octahedra, aqueous silica can decrease significantly the number of available sorption sites in Si-rich natural waters, and thus reduce both the incorporation of other trace anions and cations into iron hydroxides, and the bioavailability of their surfaces for Fe-metabolizing microorganisms (e.g., Meng et al., 2000; Santelli et al., 2001). The results on Fe-Si complex stoichiometries and structures obtained in this work may help improve models of silicate sorption by iron hydroxide phases, and abiotic or microbially catalyzed dissolution of iron silicate minerals.

Acknowledgments-We are grateful to the IF CRG commission of the ESRF for providing beam time and access to the synchrotron facility. We would like to thank Yvonne Soldo, Olivier Proux and Jean-Jacques Menthonnex for their professional assistance during XAFS measurements at BM 32 beamline. Oleg Pokrovsky is acknowledged for his generous help in solution preparation and spectra acquisition during the long and cold nights at the ESRF. Anastassia Borisova is thanked for her help in polyhedral modeling. We are indebted to Jacques Roux for his great help with software installation and running, and Jean-Michel Bény for his advice on crystallography. We are grateful to the Associate Editor, Michael Machesky, for his thoughtful comments and corrections that greatly improved the presentation and clarity of this article. We thank Jérôme Rose, Glenn Waychunas, and Dave Sherman for their careful and constructive reviews of the manuscript.

Associate editor: M. L. Machesky

\section{REFERENCES}

Anderson P. R. and Benjamin M. M. (1985) Effects of silicon on the crystallization and adsorption properties of ferric oxides. Environ. Sci. Technol. 19, 1048-1053.

Ankudinov A. L., Ravel B., Rehr J. J., and Conradson S. D. (1998) Real-space multiple-scattering calculation and interpretation of Xray-absorption near-edge structure. Phys. Rev. B 58, 7565-7576.

Apted M. J., Waychunas G. A., and Brown G. E. Jr (1985) Structure and specification of iron complexes in aqueous solutions determined by X-ray absorption spectroscopy. Geochim. Cosmochim. Acta 45, 421-429.

Baes C. F. Jr. and Mesmer R. E. (1976) The Hydrolysis of Cations. John Wiley, New York.

Bailey S. W. (1988) Odinite, a new dioctahedral-trioctahedral $\mathrm{Fe}^{3+}$ rich 1: 1 clay mineral. Clay Miner. 23, 237-247.

Bottero J.-Y., Manceau A., Villieras F., and Tchoubar D. (1994) Structure and mechanisms of formation of $\mathrm{FeOOH}(\mathrm{Cl})$ polymers. Langmuir 10, 316-319.

Carlson L. and Schwertmann U. (1981) Natural ferrihydrite in surface deposits from Finland and their association with silica. Geochim. Cosmochim. Acta 45, 421-429.

Combes J. M., Manceau A., Calas G., and Bottero J.-Y. (1989) Formation of ferric oxides from aqueous solutions: A polyhedral approach by X-ray absorption spectroscopy: I. Hydrolysis and formation of ferric gels. Geochim. Cosmochim. Acta 53, 583-594.

Combes J. M., Manceau A., and Calas G. (1990) Formation of ferric oxides from aqueous solutions: A polyhedral approach by X-ray absorption spectroscopy: II. Hematite formation from ferric gels. Geochim. Cosmochim. Acta 54, 1083-1091.

Crozier E. D., Rehr J. J., and Ingalls R. (1988) Amorphous and liquid systems. In X-Ray Absorption: Principles, Applications, Techniques of EXAFS, SEXAFS and XANES (eds. D. C. Koningsberger and R. Prins), pp. 373-442. Wiley-Interscience, New York.

Davis C. C., Chen H. W., and Edwards M. (2002) Modeling silica sorption to iron hydroxide. Environ. Sci. Technol. 36, 582-587.

Decarreau A., Bonnin D., Badaut-Trauth D., Couty R., and Kaiser P. (1987) Synthesis and crystallogenesis of ferric smectite by evolution of $\mathrm{Si}-\mathrm{Fe}$ coprecipitates in oxidizing conditions. Clay Miner. 22, 207-223.

Dietzel M. and Usdowski E. (1995) Depolymerization of soluble silicate in dilute aqueous solutions. Colloid Polym. Sci. 273, 590-597.
Doelsch E., Rose J., Masion A., Bottero J. Y., Nahon D., and Bertch P. M. (2000) Speciation and crystal chemistry of iron (III) chloride hydrolyzed in the presence of $\mathrm{SiO}_{4}$ ligands. 1. An Fe K-edge EXAFS study. Langmuir 16, 4726-4731.

Dollase W. A. (1971) Refinement of the crystal structures of epidote, allanite and hancockite. Am. Miner. 56, 447-464.

Drief A., Nieto F., and Sanchez-Navas A. (2001) Experimental claymineral formation from a subvolcanic rock by interaction with $1 \mathrm{M}$ $\mathrm{NaOH}$ solution at room temperature. Clays Clay Miner. 49, 92-106.

Dyar M. D., Delaney J. S., and Sutton S. R. (2001) Fe XANES spectra of iron-rich micas. Eur. J. Mineral. 13, 1079-1098.

Farges F. (1996) Does Zr-F complexation occur in magmas? Chem. Geol. 127, 253-268.

Farges F., Brown G. E. Jr., Navrotsky A., Gan H., and Rehr J. J. (1996) Coordination chemistry of Ti(IV) in silicate glasses and melts: III. Glasses and melts from ambient to high temperatures. Geochim. Cosmochim. Acta 60, 3055-3065.

Gehlen M., Beck L., Calas G., Flank A. M., van Bennekom A. J., and van Beusekom J. E. E. (2002) Unravelling the atomic structure of biogenic silica: Evidence of the structural association of $\mathrm{Al}$ and $\mathrm{Si}$ in diatom frustules. Geochim. Cosmochim. Acta 66, 1601-1609.

Giuli G., Paris E., Wu Z., Brigatti F., Cibin G., Montana A., and Marcelli A. (2001) Experimental and theoretical XANES and EXAFS study of tetra-ferriphlogopite. Eur. J. Miner. 13, 1099-1108.

Hair N. J. and Beattie J. K. (1977) Structure of hexaaquairon(III) nitrate trihydrate. Comparison of iron(II) and iron(III) bond lengths in high-spin octahedral environments. Inorg. Chem. 16, 245-250.

Hansen H. C. B., Raben-Lange B., Raulund-Rasmussen K., and Borggaard O. K. (1994a) Monosilicate adsorption by ferrihydrite and goethite at pH 3-6. Soil Sci. 158, 40-46.

Hansen H. C. B., Wetche T. P., Raulund-Rasmussen K., and Borggaard O. K. (1994b) Stability constants for silicate adsorbed to ferrihydrite. Clay Miner. 29, 341-350.

Hazen R. M. and Finger L. W. (1989) High-pressure crystal chemistry of andradite and pyrope: Revised procedures for high-temperature diffraction experiments. Am. Miner. 74, 353-359.

Ildefonse P., Cabaret D., Sainctavit P., Calas G., Flank A. M., and Lagarde P. (1998) Aluminium X-ray absorption near edge structure in model compounds and Earth's surface minerals. Phys. Chem. Miner. 25, 112-121.

Iler R. K. (1979) Chemistry of Silica-Solubility, Polymerisation, Colloid and Surface Properties and Biochemistry. John Wiley, New York.

Jolivet J.-P., Henry M., and Livage J. (1994) De la Solution à l'Oxyde. InterEditions and CNRS Editions, Paris, France.

Konhauser K. O. and Ferris F. G. (1996) Diversity of iron and silica precipitation by microbial mats in hydrothermal water, Iceland: Implications for Precambrian iron formations. Geology 24, 323-326.

Koroleff F. (1976) Determination of silicon. In Methods of Seawater Analysis. (ed. K. Grassnoff). Springer-Verlag, Berlin, Germany.

Lind M. D. (1970) Refinement of the crystal structure of iron oxychloride. Acta Cryst. B26, 1058-1062.

Lindqvist-Reis P., Munoz-Paez A., Diaz-Moreno S., Pattanail S., Parsson I., and Sandstom M. (1998) The structure of the hydrated $\mathrm{Ga}(\mathrm{III}), \mathrm{In}(\mathrm{III})$ and $\mathrm{Cr}(\mathrm{III})$ ions in aqueous solutions. A large angle X-ray scattering and EXAFS study. Inorg. Chem. 37, 6675-6683.

Manceau A. (1995) The mechanism of anion adsorption on iron oxides: Evidence for the bonding of arsenate tetrahedra on free $\mathrm{Fe}(\mathrm{O}, \mathrm{OH})_{6}$ edges. Geochim. Cosmochim. Acta 59, 3647-3653.

Manceau A. and Combes J. M. (1988) Structure of Mn and Fe oxides and oxyhydroxides: A topological approach by EXAFS. Phys. Chem. Miner. 15, 283-295.

Manceau A. and Charlet L. (1994) The mechanism of selenate adsorption on goethite and hydrous ferric oxide. J. Colloid Interface Sci. 168, 87-93.

Manceau A., Ildefonse P., Hazemann J. L., Flank A. M., and Gallup D. (1995) Crystal chemistry of hydrous iron silicate scale deposits at the Salton Sea geothermal field. Clays Clay Miner. 43, 304-317.

Manceau A., Chateigner D., and Gates W. P. (1998) Polarized EXAFS, distance-valence least-squares modeling (DVLS), and quantitative texture analysis approaches to the structural refinment of Garfield nontronite. Phys. Chem. Miner. 25, 347-365. 
Manceau A., Schlegel M. L., Musso M., Sole V. A., Gauthier C., Petit P. E., and Trolard F. (2000) Crystal chemistry of trace elements in natural and synthetic goethite. Geochim. Cosmochim. Acta 64, 36433662.

Marezio M. (1965) Crystal structure and anomalous dispersion of $\gamma$-LiAlO 2 . Acta Cryst. 19, 396-400.

Martell A. E., Smith R. M., Motekaitis R. J. (1998) NIST Critically Selected Stability Constants of Metal Complexes Database. Version 5.0, Users' Guide. U.S. Department of Commerce, NIST, Gaithersburg, MD.

Mayer T. D. and Jarrell W. M. (1996) Formation and stability of iron(II) oxidation products under natural concentrations of dissolved silica. Water Res. 30, 1208-1214.

McPhail M., Page A. L., and Bingham F. T. (1972) Adsorption interactions of monosilicic and boric acid on hydrous oxides of iron and aluminum. Soil. Sci. Am. Proc. 36, 510-514.

Meng X., Bang S., and Korfiatis G. P. (2000) Effects of silicate, sulfate, and carbonate on arsenic removal by ferric chloride. Water Res. 34, $1255-1261$.

Merbach A. E. and Akitt J. W. (1990) High-resolution variable pressure NMR for chemical kinetics. NMR Basic Principles Progr. 24, 190232.

Michot L. J., Montargès-Pelletier E., Lartiges B. S., d'Espinose de la Caillerie J.-B., and Briois V. (2000) Formation mechanism of the $\mathrm{Ga}_{13}$ Keggin ion: A combined EXAFS and NMR study. J. Am. Chem. Soc. 122, 6048-6056.

Olson L. L. and O'Melia C. R. (1973) The interactions of Fe(III) with $\mathrm{Si}(\mathrm{OH})_{4}$. J. Inorg. Nucl. Chem. 35, 1977-1985.

Peterson ML., Brown GE. Jr., Parks GA., and Stein CL. (1997) Differential redox and sorption of $\mathrm{Cr}(\mathrm{III} / \mathrm{VI})$ on natural silicate and oxide minerals: EXAFS and XANES results. Geochim. Cosmochim. Acta 61, 3399-3412.

Pokrovski G. S. and Schott J. (1998) Experimental study of the complexation of silicon and germanium with aqueous organic species. Implications for $\mathrm{Ge}$ and $\mathrm{Si}$ transport and the $\mathrm{Ge} / \mathrm{Si}$ ratio in natural waters. Geochim. Cosmochim. Acta 62, 3413-3428.

Pokrovski G. S., Martin F., Hazemann J.-L., and Schott J. (2000) An $\mathrm{X}$-ray absorption fine structure spectroscopy study of germaniumorganic ligand complexes in aqueous solution. Chem. Geol. 163, $151-165$.

Pokrovski G. S., Kara S., and Roux J. (2002a) Stability and solubility of arsenopyrite, FeAsS, in crustal fluids. Geochim. Cosmochim. Acta 66, 2361-2378.

Pokrovski G. S., Schott J., Hazemann J.-L., Farges F., and Pokrovsky O. S. (2002b) An X-ray Absorption Fine Structure (XAFS) and Nuclear Magnetic Resonance (NMR) spectroscopy study of galliumsilica complexes in aqueous solution. Geochim. Cosmochim. Acta 66, 4203-4322.

Pokrovsky O. S. and Schott J. (2002) Iron colloids/organic matter associated transport of major and trace elements in small boreal rivers and their estuaries (NW Russia). Chem. Geol. 190, 141-179.

Press W. H., Flannery B. P., Teukolsky S. A., and Vetterling W. T. (1986) Numerical Recipes-The Art of Scientific Computing. Cambridge University Press, Cambridge, UK.

Reardon E. J. (1979) Complexing of silica by iron(III) in natural waters. Chem. Geol. 25, 339-345.

Rose J., Manceau A., Bottero J. Y., Masion A., and Garcia F. (1996) Nucleation and growth mechanisms of $\mathrm{Fe}$ oxyhydroxide in the presence of $\mathrm{PO}_{4}$ ions. 1. Fe K-edge EXAFS study. Langmuir 12, 6701-6707.

Rose J., Flank A. M., Masion A., Bottero J. Y., and Elmerich P. (1997a) Nucleation and growth mechanisms of $\mathrm{Fe}$ oxyhydroxide in the presence of $\mathrm{PO}_{4}$ ions. 2. P K-edge EXAFS study. Langmuir 13, $1827-1834$

Rose J., Manceau A., Masion A., and Bottero J. Y. (1997b) Structure and mechanisms of formation of $\mathrm{FeOOH}\left(\mathrm{NO}_{3}\right)$ oligomers in the early stages of hydrolysis. Langmuir 13, 3240-3246.

Santelli C. M., Welch S. A., Westrich H. R., and Banfield J. F. (2001) The effect of Fe-oxidizing bacteria on Fe-silicate mineral dissolution. Chem. Geol. 180, 99-115.
Schenk J. E., Weber W. J., Jr. (1968) Chemical interactions of dissolved silica with iron.(II) and iron.(III). J. Am. Water Works Assoc. 60:199-212.

Schwertmann U. and Thalmann H. (1976) The influence of Fe(II), Si, and $\mathrm{pH}$ on the formation of lepidocrocite and ferrihydrite during oxidation of aqueous $\mathrm{FeCl}_{2}$ solutions. Clay Miner. 11, 189-200.

Schwertmann U., Taylor R. M. (1989) Iron oxides. In Minerals in Soil Environments. (eds. J. B. Dixon and S. B. Weed). SSSA, Madison, Wisconsin.

Sherman D. M. and Vergo N. (1988) Optical (diffuse reflectance) and Mössbauer spectroscopic study of nontronite and related Fe-bearing smectites. Am. Miner. 73, 1346-1354.

Sigg L. and Stumm W. (1980) The interaction of anions and weak acids with the hydrous goethite $(\alpha-\mathrm{FeOOH})$ surface. Colloids Surf. 2, 101-117.

Soldo Y., Hazemann J. L., Aberdam D., Inui M., Tamura K., Raoux D., Pernot E., Jal J. F., and Dupuy-Philon J. (1998) Semiconductor-tometal transition in fluid selenium at high pressure and temperature: An investigation using X-ray absorption spectroscopy. Phys. Rev. B: Condens. Matter 57, 258-268.

Stern E. A. (1993) Number of relevant independent points in x-rayabsorption fine-structure spectra. Phys. Rev. B: Condens. Matter 48, 9825-9827.

Swaddle T. W. (2001) Silicate complexes of aluminum (III) in aqueous systems. Coord. Chem. Rev. 219-221, 665-686.

Szytula A., Burewicz A., Dimitrijewic Z., Krasnicki S., Rzany H., Todorovic J., Wanic A., and Wolski W. (1968) Neutron diffraction studies of $\alpha-\mathrm{FeOOH}$. Phys. Status Solidi 26, 429-434.

Tagirov B. R., Diakonov I. I., Devina O. A., and Zotov A. V. (2000) Standard ferric-ferrous potential and stability of $\mathrm{FeCl}^{2+}$ to $90^{\circ} \mathrm{C}$. Thermodynamic properties of $\mathrm{Fe}^{3+}{ }_{(\text {aq })}$ and ferric-chloride species. Chem. Geol. 162, 193-219.

Teo B. K. (1986) EXAFS: Basic Principles and Data Analysis. Inorganic Chemistry Concepts 9. Springer-Verlag, Berlin, Germany.

Tessier A., Rapin F., and Carignan R. (1985) Trace metals in oxic lake sediments: possible adsorption onto iron oxyhydroxides. Geochim. Cosmochim. Acta 49, 183-194.

Toth T. A. and Fritz S. J. (1997) An Fe-berthierine from a cretaceous laterite. Parts I and II. Clays Clay Miner. 45, 564-586.

Vempati R. K. and Loeppert R. H. (1989) Influence of structural and adsorbed $\mathrm{Si}$ on the transformation of synthetic ferrihydrite. Clays Clay Miner. 37, 273-279.

Waychunas G. A. and Rossman G. R. (1983) Spectroscopic standard for tetrahedrally coordinated ferric iron: $\gamma \mathrm{LiAlO}_{2}: \mathrm{Fe}^{3+}$. Phys. Chem. Miner. 9, 212-215.

Waychunas G. A., Rea B. A., Fuller C. C., and Davis J. A. (1993) Surface chemistry of ferrihydrite: Part I. EXAFS studies of the geometry of coprecipitated and adsorbed arsenate. Geochim. Cosmochim. Acta 57, 2251-2269.

Waychunas G. A., Davis J. A., and Fuller C. C. (1995) Geometry of sorbed arsenate on ferrihydrite and crystalline $\mathrm{FeOOH}$ : Re-evaluation of EXAFS results and topological factors in predicting sorbate geometry, and evidence for monodentate complexes. Geochim. Cosmochim. Acta 59, 3655-3661.

Weber W. and Stumm W. (1965) Formation of a silicato-iron (III) complex in dilute aqueous solutions. J. Inorg. Nucl. Chem. 27, 237-239.

Wesolowski D. J., Palmer D. A., and Mesmer R. E. (1995) Measurements and control of $\mathrm{pH}$ in hydrothermal solutions. In Water-Rock Interaction (eds. Y. K. Kharaka and O. V. Chudaev), pp. 51-55. Balkema, Rotterdam, the Netherlands.

Wilke M., Farges F., Petit P. E., Brown G. E. Jr., and Martin F. (2001) Oxidation state and coordination of Fe in minerals: An Fe K-XANES spectroscopic study. Am. Mineral. 65, 713-730.

Winterer M. (1997) XAFS-A data analysis program for material sciences [abstract]. In Proceedings of the 9th International Conference on X-Ray Absorption Fine Structure (XAFS-IX): Grenoble, 1996 (eds. J. Goulon, C. Goulon-Ginet, and N. B. Brookes). J. Physique IV 7:C2-243. 